\title{
Perturbation Experiments in Community Plant Species during Recovery from Agricultural Abandonment in a Semi-Arid Region of Central-Western Spain
}

\author{
J. E. Alvarez-Diaz ${ }^{1}$, M. C. Santa-Regina ${ }^{2}$, I. Santa-Regina ${ }^{3^{*}}$ \\ ${ }^{1}$ Universidad de Antioquía, Medellín, Colombia \\ ${ }^{2}$ Instituto Arcipreste de Hita, Madrid, Spain \\ ${ }^{3}$ IRNASA-CSIC, Cordel de Merinas, Salamanca, Spain \\ Email: *ignacio.santaregina@irnasa.csic.es
}

How to cite this paper: Alvarez-Diaz, J.E., Santa-Regina, M.C. and Santa-Regina, I. (2016) Perturbation Experiments in Community Plant Species during Recovery from Agricultural Abandonment in a Semi-Arid Region of Central-Western Spain. Journal of Environmental Protection, 7, 1618-1644. http://dx.doi.org/10.4236/jep.2016.711133

Received: August 30, 2016

Accepted: October 28, 2016

Published: October 31, 2016

Copyright (c) 2016 by authors and Scientific Research Publishing Inc. This work is licensed under the Creative Commons Attribution International License (CC BY 4.0).

http://creativecommons.org/licenses/by/4.0/

\begin{abstract}
Background: Can high diversity mixtures of later succession plant species be able to suppress early successional (arable weed) species than low diversity species mixtures? Can the removal of plant functional groups have important consequences on the system stability? Location: The study area was located at $850 \mathrm{~m}$ a.s.l., fifteen kilometers $(15 \mathrm{~km})$ to the west of Salamanca city, Spain, in a dehesa-like woodland. Methods: The field experiment was installed in Spring 1996 (May). The plots represented former agricultural lands cropped with (a rotation of) monocultures and abandoned right at the beginning of the experiment after the last crop was harvested in 1995. Before installing plots, the fields were harrowed and equalized. The treatments (NC-natural colonization, LD-low diversity seed mixture and HD-high diversity seed mixture) were randomly allocated to the plots in each block. The experiment was organised according to a block design with five replicate blocks. Within each block, four plots measuring $10 \times 10 \mathrm{~m}$ were marked out and each of the three treatments was randomly assigned to one plot. All plots were separated by $2 \mathrm{~m}$ walkways. Results: The competitive ability of the sown species in different mixtures in $\mathrm{LD}$, valued on the basis of their performance in HD, is a good predictor of their ability to suppress the weed crops species. This was also corroborated by the high relationship between the efficiency of the sown species in both treatments of species mixture $\left(\mathrm{R}^{2}=0.51, \mathrm{~F}(1,33)=34.56, P<0.001\right)$. Conclusions: The increase of colonizing species cover was significantly lower in $\mathrm{LD}$, which again supported the increase of biomass in 1998, being also lower in HD. Therefore, this increase in the community is more prominent in LD treatments. The effect of sown species was not so important in this increase.
\end{abstract}




\section{Keywords}

Colonization, Ecosystem Functioning, Invasibility, Restoration,

Sowing Experiment, Species Richness

\section{Introduction}

In the debate of threats to biological diversity and ecosystem functioning, land use change has been identified as one of the most immediate causes [1] [2] [3] [4]. Diversity losses in plant communities can limit plant recruitment and deplete plant productivity, which will cause transient effects on the functioning of the ecosystem [5]. There is a growing awareness of how agricultural practices reduce diversity, not only of plants but also of soil microorganisms [6]. Today, substantial effort is made to restore diversity of former arable land. Indeed, management modifying the initial plant community increases the rate of transfer towards more natural grasslands or forest communities [7] [8].

Since the dynamics of secondary succession are much faster than those of primary succession, it has enabled experimental testing of several theories on dispersal, colonization and establishment [9]. Therefore, studying old field succession has both fundamental and applied value [10]. Nevertheless, the predictability of old field succession and the effects of various management strategies still need improvement. Recent works suggest that changes in species trait composition during succession can be better predicted than species composition itself [11].

The relationship between diversity and stability has been a controversial issue for decades [12] [13]. The existence of niche differences between species suggests that more diverse communities would be buffered against environmental variations because the probability that they contain species capable of performing well under each of the different environmental conditions is higher than for less diverse communities [14]. Nevertheless, some models have demonstrated that higher diversity can result to lower stability [15]. As shown by Tilman et al. [16], both may be correct: the stability of individual population decreases with diversity, but the stability of parameters aggregated at the ecosystem level increases with diversity. The relationship between diversity and stability derived from studies across environmental gradients is not determined by the same mechanisms as the relationship between diversity and stability obtained by the loss of species in a given ecosystem, and these relationships should not be expected to be simi$\operatorname{lar}[17]$ [18].

A number of rather short-term experiments carried out by van der Putten et al. [8]; Lepš et al. [19]; Hedlund et al. [20] have indicated that, on average, species-rich mixtures are more productive and also more efficient in suppressing weed species and preventing further colonization than species-poor mixtures [8] [21] [22] [23], with some low diversity mixtures being as productive and as efficient as the high diversity mixtures; those successful low diversity mixtures are usually composed of species domi- 
nating the high diversity mixtures [18] [24] [25]. Several experiments studying the effects of sowing species mixtures on vegetation development had been conducted for a limited period of time, and some were accompanied by weeding [26].

In recent years, there has been a lively debate on the nature and the importance of competition as determinant of the structure and dynamics of plant communities [7] [28] [29] [30] [31]. An important aspect of the controversy is the disagreement on the characteristics of successful competitors. Tilman [28] defines a high competitive ability as the capacity to reduce a resource to a level too low to support the growth of competitors. He postulates that due to the physical separation of above- and below-ground resources, plant faces an unavoidable trade-off between the abilities to compete for these resources: in order to obtain a higher portion of one resource, plants must allocate more biomass to structures involved in the acquisition of that resource at the expense of allocation of biomass to structures involved in the acquisition of another resource.

A growing body of experimental evidence supports the hypothesis that ecosystem properties are mostly influenced by the characteristics of dominants plants [26]. From the data analysis, no great differences regarding the number of perennial species along the years are shown; but rather, the number of annual species varies greatly (data not shown). This variability can due to the different abundance of the former, and surely also due to other intrinsic feature, such as dispersion ability, or because annuals have not yet germinated in autumn when leaching and uptake begins by perennials and when other species are not present [32]. Van der Putten et al. [8] indicated the overall effect of biomass on suppression of arable weed species, but mechanisms (germination suppression vs. resource competition) may be different.

The present study focuses on the suppression of early-successional (arable weed) species by more or less diverse species mixtures of later-successional plant species. The diversity treatments comprised four (low diversity) or fifteen (high diversity) plant species. Low diversity assemblages varied between replicates in order to take account of sampling effects [33]-[39]. In order not to exclude dominants from the mixtures [26] or plant species with special traits (such as legumes), plants were stratified into three species groups (grasses, legumes, and other forbs), all of which were present in both diversity treatments.

The hypothesis that high diversity mixtures of later succession plant species were able to suppress early successional (arable weed) species than low diversity species mixtures was tested. Arguments for this hypothesis may be derived from Elton's [13] hypothesis on invasiveness. According to Elton [13], exotics will more likely invade areas with low species diversity than areas with high species diversity. However, there are also many arguments that don't support Elton's hypothesis [40], so that our alternative hypothesis will be that plant species diversity does not matter for suppressing earlysuccession species. The main aim of this study was to assess the sowing effect of plant species on the establishment and performance of first sown plant species in holding the abandoned fields during all period of experimentation. Furthermore, it was tested if the 
mixtures of plant sown species in high diversity treatment were more effective in removing the weed species present in the seed bank of soil.

\section{Materials and Methods}

\subsection{Site Description}

The study area was located at $850 \mathrm{~m}$ a.s.l. Fifteen kilometers $(15 \mathrm{~km})$ to the west of Salamanca city, Spain (its coordinates: $40^{\circ} 54^{\prime} 00^{\prime \prime} \mathrm{N}, 5^{\circ} 45^{\prime} 30^{\prime \prime} \mathrm{W}$ ), where a 1 ha experimental plot was chosen at the Muñovela experimental farm (C.S.I.C). The plot is edaphically homogenous, with a dehesa-like woodland. Previously, it was heavily grazed although it is now fenced off to prevent the access of domestic animals.

The climate of the zone features rainy winters and hot summers and may be classified as semi-arid Mediterranean $\left(\mathrm{C}_{1} \mathrm{~B}_{1}{ }_{1} \mathrm{~S}_{2} \mathrm{~b}_{4}{ }_{4}\right)$. Long-term mean rainfall and temperature have values of $500 \mathrm{~mm}$ and $12.3^{\circ} \mathrm{C}$, with November being the rainiest month (99 $\mathrm{mm})$ and July the driest $(17 \mathrm{~mm})$. January is normally the coldest month $\left(0.8^{\circ} \mathrm{C}\right)$.

The tree covering comprises Quercus rotundifolia Lam, with a density of 98 trees $\mathrm{ha}^{-1}$, a mean height of $5.9 \mathrm{~m}$ and mean diameter of $29.1 \mathrm{~cm}$. Chorologically, the area lies in the Mediterranean Region, Carpetano-Ibérico-Leonesa province, Salmantino sector, Genisto hystricis-Querceto-rotundifoliae sigmetum series. The estimated mean age of the trees was 150 years. Other characteristic species defining the series are: Doryncium pentaphyllum, Thymus zygis, T. mastichina and Crataegus monogyna.

The soil is a chromic Luvisol [41], developed over red clays and Miocene conglomerates. Soil texture A/B is loam/clay, the slope of the plot is $2 \% . \mathrm{pH} \mathrm{H}_{2} \mathrm{O}: 6.3, \% \mathrm{CO}_{3} \mathrm{Ca}$ : 0.07, \% Organic matter: 2.14, P total (mg per $100 \mathrm{~g}$ ): 298, N total (mg per $100 \mathrm{~g}$ ): 731, $\mathrm{Na}$ (mEq per $100 \mathrm{~g}$ soil): 39.6, K (mEq per $100 \mathrm{~g}$ soil): 56.3, Mg (mEq per $100 \mathrm{~g}$ soil): 260, $\mathrm{CaCl}_{2}$ (mEq per $100 \mathrm{~g}$ soil): 16 .

\subsection{Experimental Design}

A field experiment was carried out on abandoned arable land with sown low and high diversity treatments and natural colonisation following typical farming practice for the site. In April-May 1996, experimental plots were installed on former agricultural land that had been cropped with (a rotation of) monocultures until the end of 1995. The experiment was organised according to a block design with five replicate blocks. Within each block, four plots measuring $10 \times 10 \mathrm{~m}$ were marked out and each of the three treatments was randomly assigned to one plot. All plots were separated by $2 \mathrm{~m}$ walkways. The three treatments (LD-low diversity seed mixture, HD-high diversity seed mixture and NC-natural colonization) were randomly allocated to the plots in each block.

As the initial vegetation development at abandoned land is usually highly unstable and unpredictable, late-successional types of functional groups of plants were experimentally sown in both low and high diversity mixture. Based on the specific characteristics of plants, the functional groups most widely recognised in tempered grassland communities and used in this study are (1) grasses, (2) legumes and (3) other forbs. The 
low and high diversity mixtures consisted of the same amounts of seed (grasses: 2500 seeds. $\mathrm{m}^{-2}$, legumes: 500 seeds $\mathrm{m}^{-2}$, and other forbs also 500 seeds $\cdot \mathrm{m}^{-2}$ ). Fifteen species (five per functional group) were sown as the high diversity sown treatment. For the low diversity sown treatment, low diversity seed mixtures (two grasses, one legume and one other forb species) were used as random choices from the total set of plants available for each replicate in order to take account of the sampling effects. The plant mixtures used consisted of species typical of later successional stages expected (Table 1).

\subsection{Data Recording and Statistical Analyses}

The data were analysed by repeated measures ANOVA ( $P$-values), for number of sown species, number of unsown, i.e. colonizing species, total number of plant species and proportion of the sown species calculated on the basis of cover. In the model, treatment (NC, LD, HD) was the fixed factor, block nested was the random factor while year was the repeated measures factor. Number of species applies for the pooled sample of 12 quadrants, $1 \mathrm{~m}^{2}$ each, in the whole-plots and in subplots (averaged over the 12 plots). The ecologically most interesting tests are for the effect of treatment, and the interaction between treatment and year. Significant effects of treatment and treatment by year interactions; would show that there is a consistent effect of treatment, either constant over years (treatment), or variable over the years (treatment $\times$ year interaction). To test

Table 1. Density of sown seeds (seeds. $\mathrm{m}^{-2}$ ) in the five blocks of low diversity treatments (LDS1 to LDS5) and in the plots of high diversity treatments (HDS).

\begin{tabular}{|c|c|c|c|c|c|c|c|}
\hline Grasses & & LD1 & LD2 & LD3 & LD4 & LD5 & $\mathrm{HD}$ \\
\hline Bromus inermis Leyss. & BromIner & & 1250 & 1250 & & & 500 \\
\hline Festuca rubra L. & FestRubr & 1250 & & & & 1250 & 500 \\
\hline Phleum pratense $\mathrm{L}$. & PhlePrat & 1250 & 1250 & & & & 500 \\
\hline Poa pratensis $\mathrm{L}$. & PoaPrat & & & & 1250 & 1250 & 500 \\
\hline Poa trivialis $\mathrm{L}$. & PoaTriv & & & 1250 & 1250 & & 500 \\
\hline \multicolumn{8}{|l|}{ Legumes } \\
\hline Lotus corniculatus $\mathrm{L}$. & LotuCorn & 500 & & & & & 100 \\
\hline Medicago lupulina L. & MediLupu & & & 500 & & & 100 \\
\hline Trifolium fragiferum $\mathrm{L}$. & TrifFrag & & & & & 500 & 100 \\
\hline Trifolium pratense $\mathrm{L}$. & TrifPrat & & 500 & & & & 100 \\
\hline Trifolium subterraneum L. L. & TrifSubt & & & & 500 & & 100 \\
\hline \multicolumn{8}{|l|}{ Forbs } \\
\hline Achillea millefolium $\mathrm{L}$. & AchiMill & & & 500 & & & 100 \\
\hline Galium verum $\mathrm{L}$. & GaliVeru & & & & 500 & & 100 \\
\hline Matricaria chamomilla L. & MatrCham & & & & & 500 & 100 \\
\hline Plantago lanceolata L. & PlanLanc & 500 & & & & & 100 \\
\hline Sanguisorba minor Scop. & SangMino & & 500 & & & & 100 \\
\hline
\end{tabular}


the effect of sowing different numbers of species (same number of seeds of the three functional groups, but differing in the diversity within the functional groups), an ANOVA comparing LD and HD plots was also carried out. Since in LD plots, sown species composition differed among the replicates, the performance of the "best" LD plot (i.e. the plot showing maximum proportion of sown species, maximum suppression of natural colonizers, etc) with the HD treatment was also compared.

If there is an important species identity effect, then the performance of particular LD mixtures can be predicted from the species performances in the HD plots. The following procedure was used: for each of the sown species, the average "importance" (average value of cover abundance) over all the HD plots was calculated. For each LD mixture, the sum of importance of its constituent species was then calculated, and this value was used as a predictor of the performance of LD mixture. The species importance in HD plots should be proportional to its competitive ability, and consequently, the total for the particular LD species combination should be a good predictor of its ability to suppress the other species (note that it is important that this total is completely independent of the performance of species in LD plots).

The first comparison was by varying the number of treatments. One analysis was performed with natural colonization (NC), low diversity (LD) and high diversity (HD) to compare the effect of sowing with spontaneous development of vegetation. A second analysis concerning LD and HD only, to examine the effect of diversity was also performed. All treatment means were compared by Tukey's HSD.

Various diversity indexes (Shannon [42], Camargo [43] and Q statistics [44] and (Shannon and Berger-Parker [45] based on the proportional abundance of species were established (Table 2).

The heterogeneity of the vegetation might be an important factor for increasing the richness of vegetation at the scale of the whole-plot. Heterogeneity was characterized by taking the average of standardized Euclidean distance (chord distance) between all pairs of subplots within a whole-plot. Chord distance is classical ED calculated after standardization by sample norm, i.e. after each value is divided by the norm of the vector characterizing the community where $x_{i}$ is representation of $i$-th species in the sample [46].

\section{Results}

\subsection{Suppression of Colonizer Species}

Between both sowing treatments, no significant differences in the number of colonizing species were detected $(\mathrm{F}=0.81,1 \mathrm{df}, \mathrm{P}=0.42)$. During all experimental process, a similar behavior was observed (Figure 1), such that no significant differences were found between the treatment $x$ year interaction $(\mathrm{F}=6.46,6 \mathrm{df}, \mathrm{P}=0.87)$. The number of colonizing species in the treatments of sowing LD-HD species mixtures for each of the blocks (B) sampled for seven years was recorded (Figure 2). To eliminate the blocks effect, an analysis (PCA) with the composition of colonizing species was established (Figure 3), which highlights the heterogeneity shown by the communities, such that 


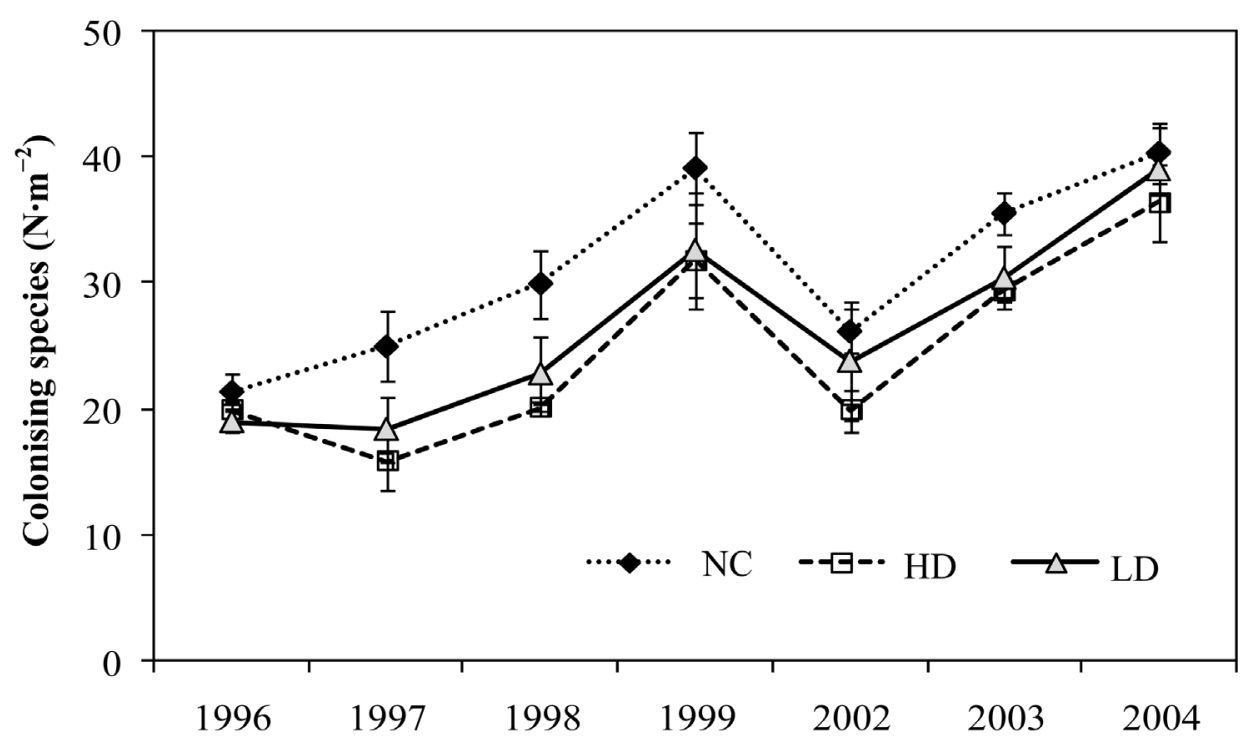

Figure 1. Annual number of colonising species in $\mathrm{NC}(\boldsymbol{}), \mathrm{LD}(\triangle)$ and $\mathrm{HD}(\square)$ treatment.

Table 2. Description of diversity and equitability indexes.

\begin{tabular}{|c|c|c|}
\hline Index & Formula & Description \\
\hline \multicolumn{3}{|c|}{ Species richness indexes } \\
\hline Shannon index & $H=-\sum_{i=1}^{n} p_{i} \ln p_{i}$ & $\begin{array}{l}p_{i}=n / n, n_{i} \text { abundance of each species } i \text { and } n \\
\text { is the number of species in each whole-plot. }\end{array}$ \\
\hline Statistical index $Q$ & $Q=\frac{\frac{1}{2} S_{q 1}+\sum S_{Q}+\frac{1}{2} S_{q 2}}{\ln n_{q 2}-\ln n_{q 1}}$ & $\begin{array}{c}1 / 2 S_{q 1} \text { : half number of species } \\
\text { in the bottom quarter }(25 \%) \text { and } \\
1 / 2 S_{q 2}: \text { in the top quarter }(75 \%) \\
\text { of accumulated species number. } \\
\sum \text { is the total number of species between } \\
\text { the bottom and top quarters. } \\
n_{q 1} \text { y } n_{q 2}: \text { are the numbers of individual } \\
\text { in each of the both quarters. }\end{array}$ \\
\hline Camargo index & $D=S-\left(\sum_{h}^{K}\left|\boldsymbol{p}_{i h}-\boldsymbol{p}_{j h}\right|\right)$ & $\begin{array}{c}S: \text { species richness, } \boldsymbol{p}_{i h} \text { and } \boldsymbol{p}_{j h}: \text { relative } \\
\text { abundance of specie } i \text { and } j . \\
K \text { : interactions between species. }\end{array}$ \\
\hline Simpson and & $D=1 /$ Simpson & $D$ is the proportion squared \\
\hline Berger-Parker index & $D=1 /$ Berger-parker & of the sum of all community species \\
\hline \multicolumn{3}{|c|}{ Evenness and dominante indexes } \\
\hline Shannon index & $E=\frac{H^{\prime}}{\ln S}$ & \\
\hline Camargo index & $E=1-\left[\left(\sum_{h}^{K}\left|\boldsymbol{p}_{i h}-\boldsymbol{p}_{j h}\right|\right) / S\right.$ & \\
\hline $1 /$ Simpson index & $E=1 / D / S$ & \\
\hline Simpson index $(D)$ & $D=\sum_{i=1}^{s}\left(\frac{n_{i}}{N}\right)$ & $\begin{array}{l}n_{i} \text { abundance of each species } \dot{;} \\
N: \text { total sum of abundance of all species } \\
\text { and } s \text { is the total species number. }\end{array}$ \\
\hline Berger-Parker index $(d)$ & $d=A_{\max } / \sum A_{\imath}$ & $\begin{array}{l}A_{\max } \text { is the relative abundance } \\
\text { in the more abundant species. }\end{array}$ \\
\hline
\end{tabular}




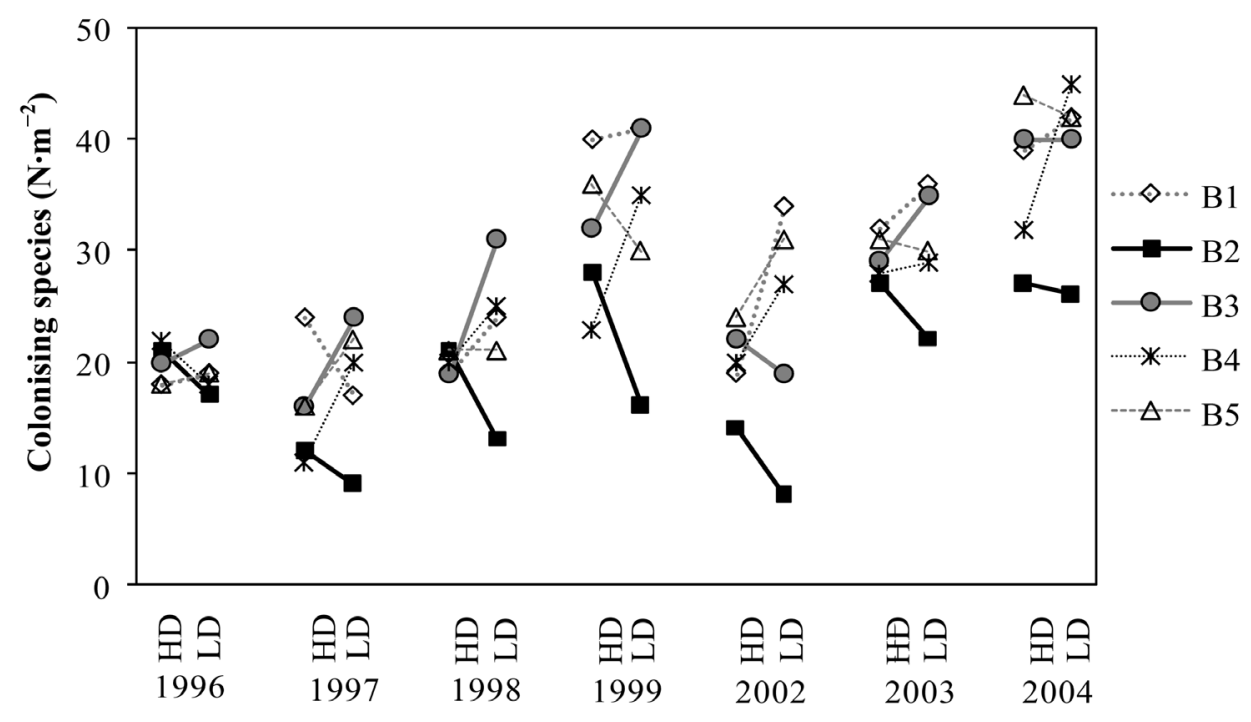

Figure 2. Number of colonising species in HD and LD for each of the five blocks (B) for the experimental sampling period.

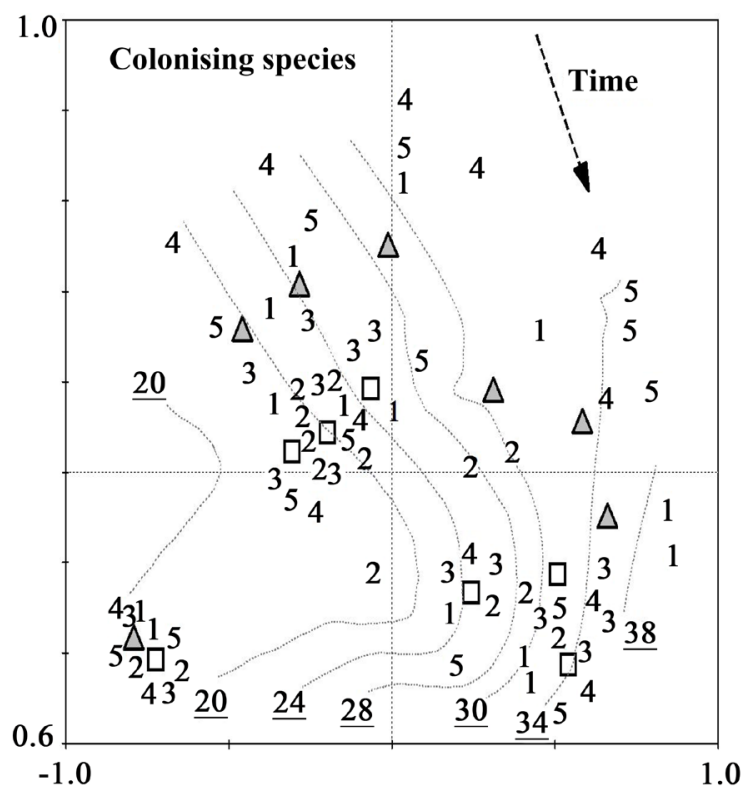

Figure 3. PCA of species composition of colonising species in LD $(\triangle)$ and HD $(\square)$ treatments. Numbers are shown for each of the five blocks (B) for the experimental sampling period.

the correlation between species and treatments was very high (Axis $1=0.97$, Axis $2=$ $0.85)$.

The relationship between suppression of colonizing species, expressed as the ratio of the average number per year of colonizing species in HD of about NC (HD/NC) species, and the dominance index D1 found for the NC, based on the dominance of the most abundant species in each block is shown in Figure 4.

The annual results expressed as block showed that blocks of the same year presented a totally different behaviour even in the NC treatment (Figure 5). These results were 


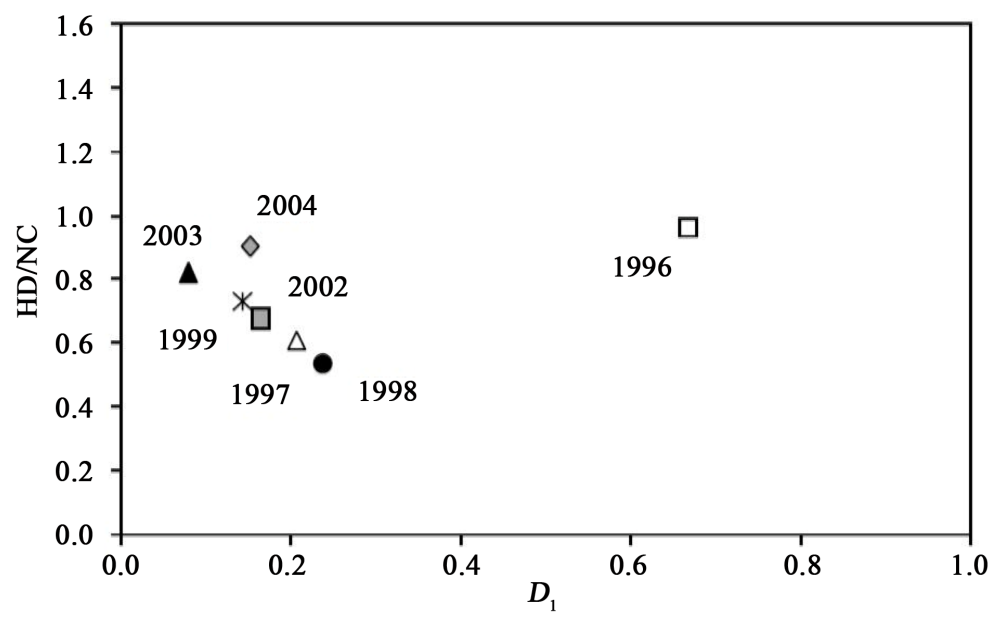

Figure 4. Relationship between the suppression of colonising expressed as ratio of the average number of colonising species to that in NC (HD/NC), and index of dominance $D_{1}$. NC ( $(\Delta)$, LD $(\triangle)$ and HD ( $\square)$ treatment.

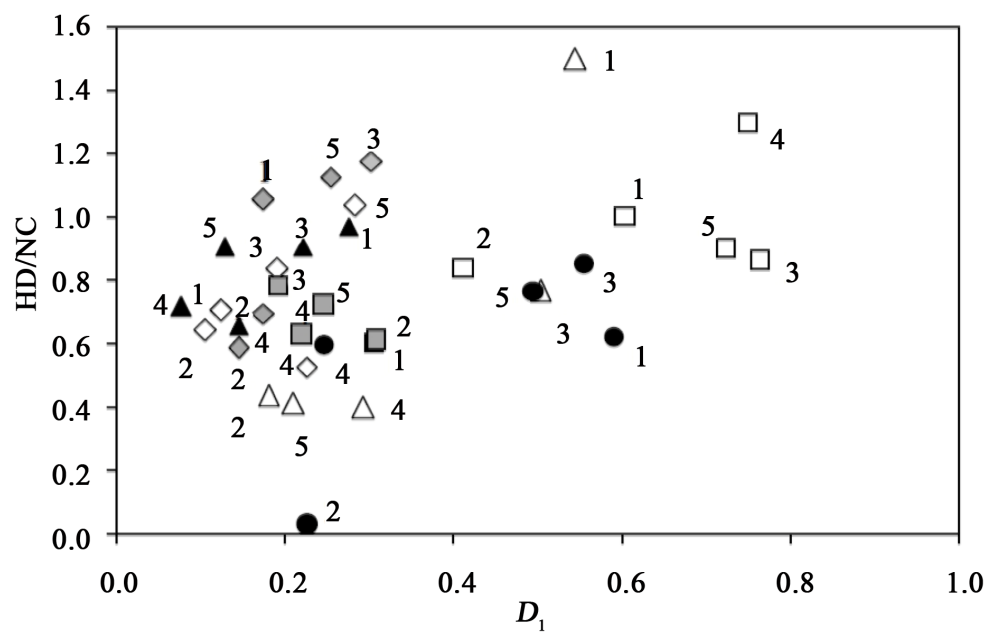

Figure 5. Relationship between the suppression of colonising expressed as ratio of the average number of colonising species to that in $\mathrm{NC}(\mathrm{Hd} / \mathrm{NC})$, and index of dominance $D_{1}$. In this case annual numbers are shown for each of the five blocks (B) for the experimental sampling period. $1996(\square), 1997(\triangle), 1998(\bigcirc), 1999(\diamond), 2002(\square), 2003(\Delta)$ y $2004(\diamond)$.

corroborated relating the index $D 1$, based on the behavior of the most abundant species, with the number of dominant species by NC block calculated according to Camargo (1992) dominance index (Figure 6).

\subsection{Dominance of Sown Species}

A significant and negative relationship $(\mathrm{r}=-0.77, \mathrm{P}<0.001)$ between the number of colonizing species in LD and performance of sowing species in $\mathrm{HD}$ was obtained (Figure 7), so the competitive ability of the sown species in different mixtures in LD, valued on the basis of their performance in HD, is a good predictor of their ability to suppress the weed crops species. This was also corroborated by the high relationship between the 


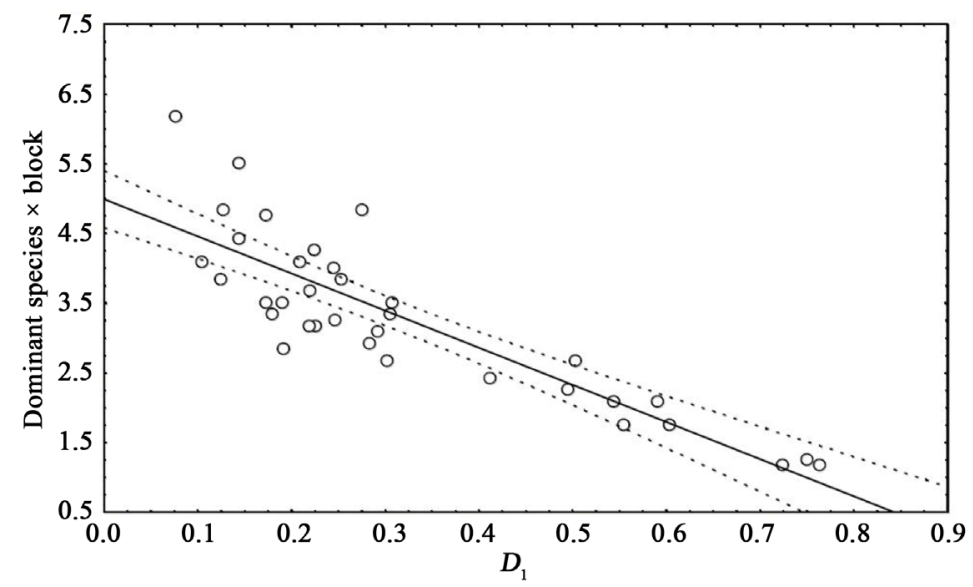

Figure 6. Relationship between the index of dominance $D_{1}$ and the number of dominant species found per block in the NC treatment $\left(\mathrm{R}^{2}=0.75 ; \mathrm{F}_{(1,33)}=98.27 ; P<0.000\right)$.

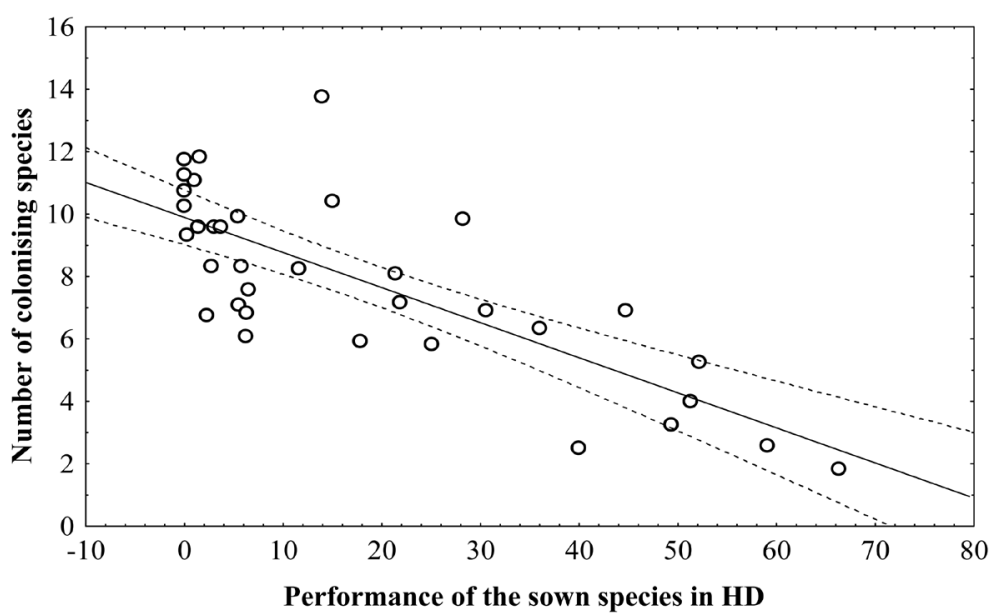

Figure 7. Relationship between the number of colonising species in LD treatment and performance of the shown species in HD treatment, calculated as the sum of the abundance of the sown species that make a mixture in the LD treatment for each block. The $95 \%$ confidence intervals for all joint years of sampling are shown. $\left(\mathrm{R}^{2}=0.60 ; \mathrm{F}_{(1,33)}=49.62 ; P<0.001\right)$.

efficiency of the sown species in both treatments of species mixture $\left(\mathrm{R}^{2}=0.51, \mathrm{~F}(1,33)\right.$ $=34.56, P<0.001)$.

PCA explains $64 \%$ of the variability of sown species cover (eigen values: Axis $1=0.36$ and Axis $2=0.28$ ), in which a complete separation between the blocks of both treatments was not observed. In all experimental time, only the confluence of blocks 2 and 3 was presented. Instead, the blocks 1,4 and 5 are located on opposite sides of the main axis 1, because the cover of certain species was more important in HD and little or none in $\mathrm{LD}$ (Figure 8).

Similarly, there were no significant differences between LD and HD treatments with respect to mean and minimum biomass ( $\mathrm{F}=2.38 ; 1$ d.f ; $\boldsymbol{P}=0.20$ ), but occasionally, there were significant differences for same years $(\mathrm{F}=28.14 ; 1$ d.f; $\boldsymbol{P}<0.000)$ and also in the treatmentx year interaction ( $\mathrm{F}=3.55 ; 1$ d.f; $\boldsymbol{P}=0.01)$. In 1998 , the biomass in- 


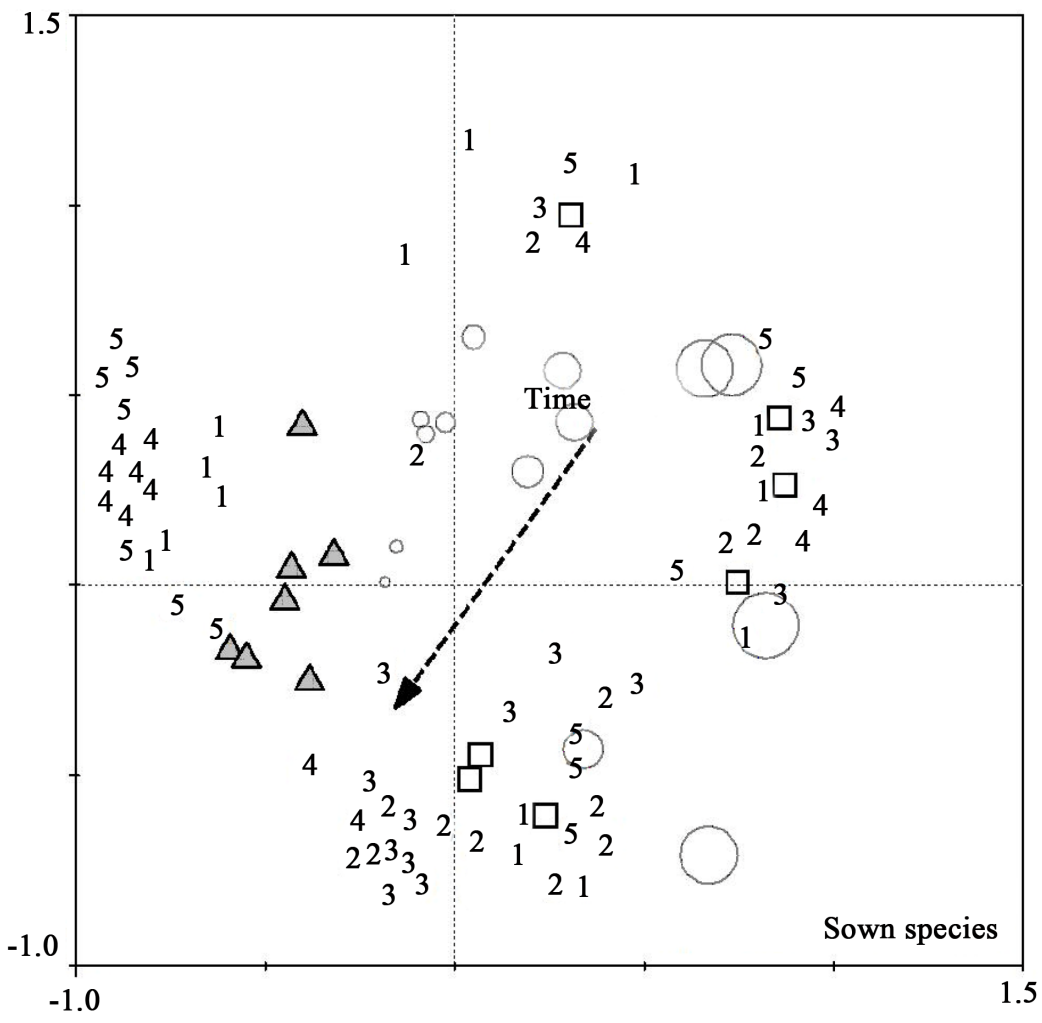

Figure 8. PCA of species composition of sown species in LD $(\triangle)$ and HD $(\square)$ treatments. The numbers of the five sampling blocks during the experimental period (time) are shown, in italics (LD) and in bold (HD). The circles represent the relative abundance of each sown species.

creased significantly in the two sown treatments and remained constant in the others (Figure 9). The grasses are the group that greatly contributes to the biomass increase in 1998; they also presented consistent differences in the treatment $\times$ year interaction $(\mathrm{F}=$ $1.81 ; 1$ d.f.; $\boldsymbol{P}=0.04$ ), whereas it was nearly significant for the other forbs group (F = 2.39; 1 d.f.; $\boldsymbol{P}=0.06$ ) and null for the legumes group (F $=0.23 ; 1$ d.f.; $\boldsymbol{P}=0.96$ ).

The blocks presented behaviours that are more homogeneous among themselves in HD sown species, whereas there were consistent differences between blocks in LD treatments, such that only the blocks 2 and 3 were similar in eliminating colonizer plant species in HD. However, 1998 was the only year where the large total biomass attained in both treatments was correlated with the high suppression of colonizer plant species by the combined effect of sown species and dominant species in natural conditions (Figure 10).

Diversity profiles of the sown species in LD and HD treatments during the experimental period, for each block and all experimental sampling period average cover degree is plotted against its rank within the sown species (Figure 11).

Relationship between the cover of sown species in LD and HD treatments for the experimental sampling period is shown in Figure 12. B. inermis was perhaps, the only species which attained high values of cover in both treatments, and therefore displayed competitively other sown species, but only those of the same functional group. 


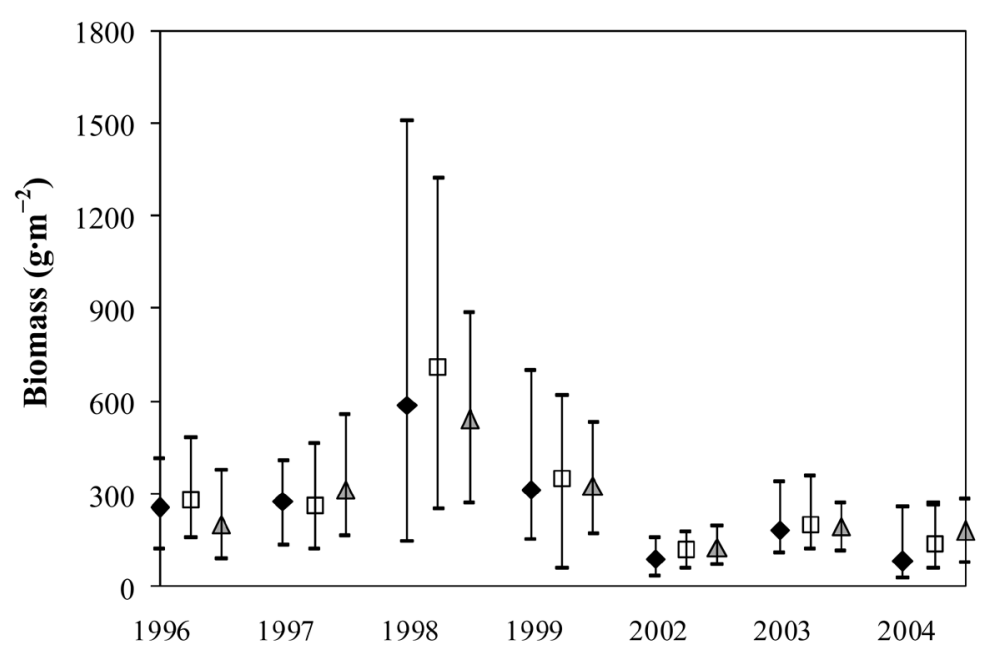

Figure 9. Maximum, average and minimum amounts of biomass in the NC $(>), H D(\square)$ and LD $\triangle)$ treatments. The maximum and minimum (whiskers) are the extreme values among the five blocks, the value for each block is the average for four $0.0625-\mathrm{m}^{2}$ subplots.

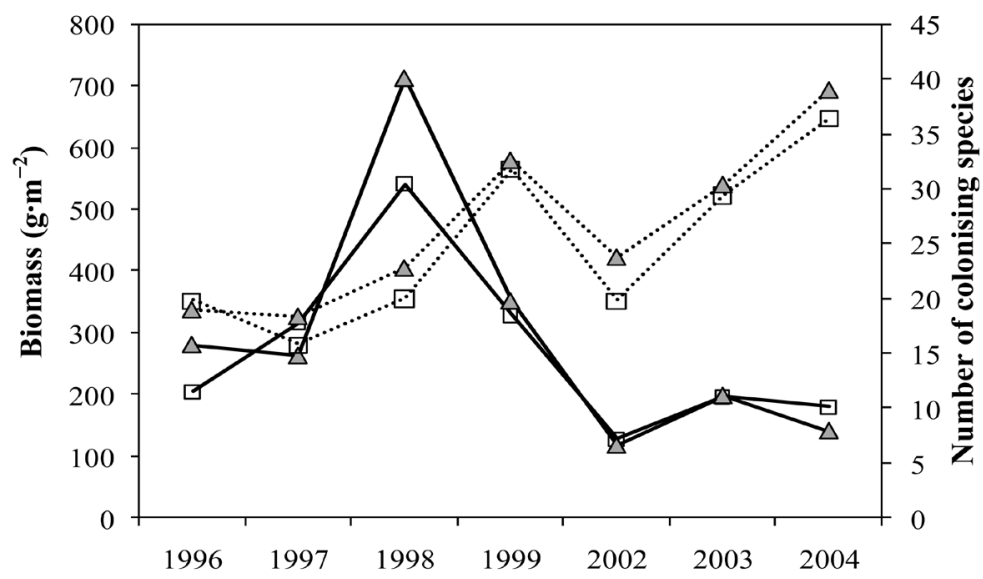

Figure 10. Relationship between the total biomass (solid line) and the number of colonising species (dotted line) in LD $(\Delta)$ and HD $(\square)$ treatments for the experimental sampling period.

\subsection{Performance of the Sown Species}

The individual behaviour of sown species was estimated on the basis of their performance in HD (Table 3). At the end of the experimental period, the mixed sown species in LD which had the best performance coincided with the best performance of the same species in HD. The more successful species during all experimental period was $B$. inermes, followed by Plantago lanceolada.

The individual performance comparison of sown species according to their functional group differs considerably, for example, many grasses disappear quickly without becoming dominant (Figure 13).

Mostly, in all the years of the study, there was a repetitive model in response to treatments of total biomass (Figure 14) and the number of colonizer species (Figure 15 ), because the treatment $\times$ year interaction for these two variables was not significant. 

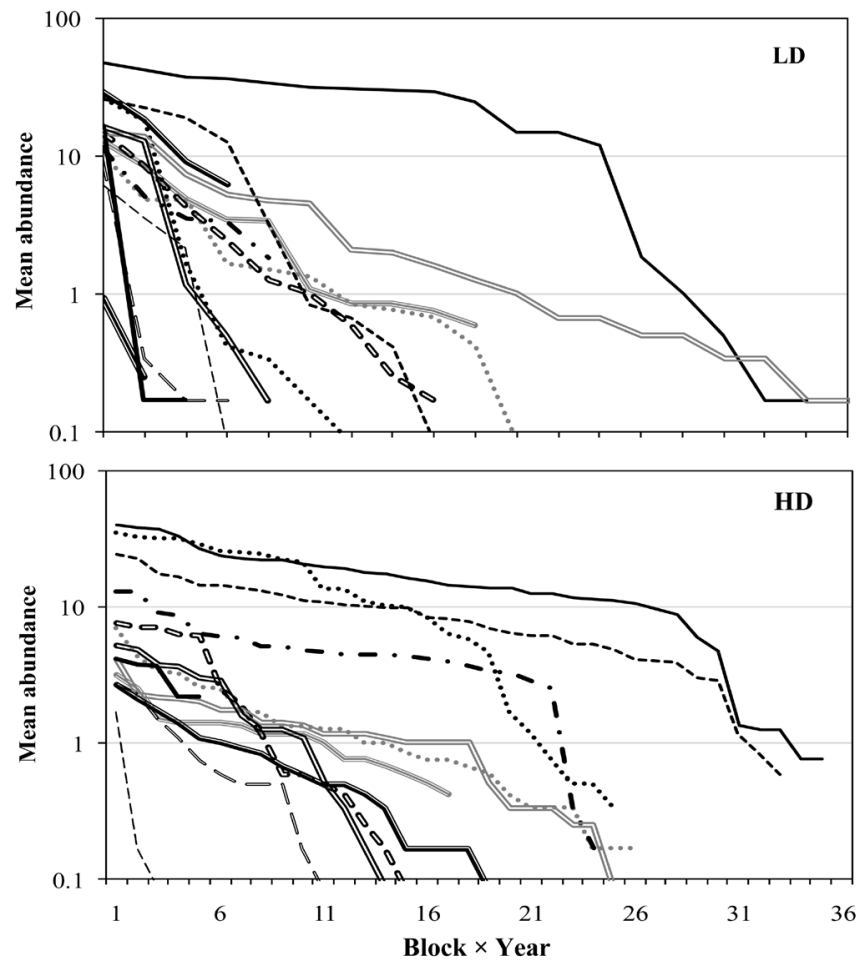

Figure 11. Diversity profiles of the sown species in LD and HD treatments. For each block and all experimental sampling period, average cover degree is plotted against its rank within the sown species. The block $\times$ year is cover in $\mathrm{LD}$, due to the blocks which represent mixtures of sown species.

Table 3. Annual performance of the sown species in HD. Fr96, Fr99 and Fr04: frequency (\%) in the first, intermediate and final year respectively. Cmax: highest cover. CM96 and CM04: mean cover at the Start and the end of the experiment.

\begin{tabular}{ccccccc}
\hline Especies & Fr96 & Fr99 & Fr04 & Cmax & CM-96 & CM-04 \\
\hline Grasses & & & & & & \\
\hline Bromus inermis & 53.33 & 100 & 93.33 & $\mathbf{4 3 . 2 2 ( 0 2 )}$ & 1.30 & $\mathbf{2 4 . 0 9}$ \\
Festuca rubra & 83.33 & 16.67 & 1.67 & $\mathbf{2 . 3 9 ( 9 6 )}$ & 2.4 & 0.23 \\
Phleum pratense & 96.67 & 8.33 & 0 & $\mathbf{8 . 2 0}(\mathbf{9 6})$ & 8.20 & $\mathbf{0}$ \\
Poa pratensis & 73.33 & 48.33 & 11.67 & $\mathbf{2 . 1 8 ( 9 8 )}$ & 1.65 & 0.39 \\
Poa trivialis & 1.67 & 0 & 1.67 & $\mathbf{0 . 5 0 ( 0 4 )}$ & 0.02 & 0.56 \\
Forbs & & & & & & \\
Achillea millefolium & 1.67 & 20 & 15 & $\mathbf{2 . 8 1 ( 0 2 )}$ & 0.05 & 1.40 \\
Galium verum & 0 & 0 & 0 & 0 & 0 & 0 \\
Matricaria chamomilla & 3.33 & 0 & 0 & $\mathbf{0 . 0 6}(\mathbf{9 6})$ & 0.06 & 0 \\
Plantago lanceolata & 98.33 & 78.33 & 10 & $\mathbf{4 0 . 5 7 ( 9 7 )}$ & 12.64 & 0.41 \\
Sanguisorba minor & 88.33 & 93.33 & 60 & $\mathbf{1 9 . 5 6 ( 0 2 )}$ & 5.24 & $\mathbf{1 2 . 0 8}$ \\
Legumes & & & & & & \\
Lotus corniculatus & 98.33 & 85 & 0 & $\mathbf{9 . 5 7 ( 9 9 )}$ & 5.60 & 0 \\
Medicago lupulina & 51.67 & 1.66 & 0 & $\mathbf{1 . 8 3 ( 9 6 )}$ & 1.83 & 0 \\
Trifolium fragiferum & 38.33 & 18.33 & 0 & $\mathbf{1 . 0 0 ( 9 9 )}$ & 0.85 & 0 \\
Trifolium pratense & 98.33 & 3.33 & 0 & $\mathbf{4 . 7 6 ( 9 6 )}$ & 4.76 & $\mathbf{0}$ \\
Trifolium subterraneum & 80.00 & 0 & 0 & $\mathbf{3 . 8 7}(\mathbf{9 6})$ & 3.87 & 0
\end{tabular}



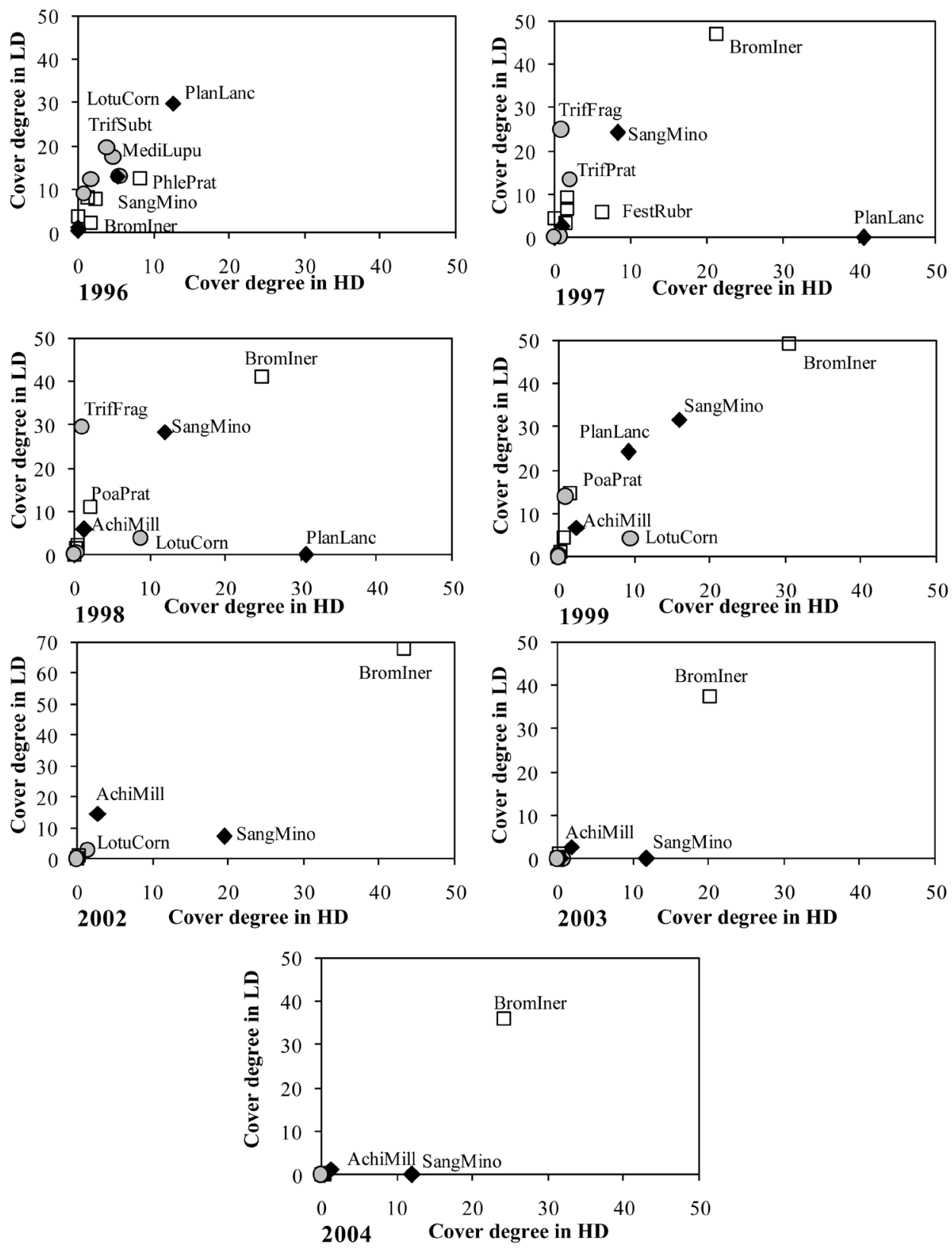

Figure 12. Relationship between the cover of sown species in LD and HD treatments for the experimental sampling period. Grasses $(\square)$, legumes $(\mathbf{O})$ and forbs $(\diamond)$.

Comparing this interaction and taking into account only the sowing of later-successional plant species in LD and high-diversity HD treatments, the number of colonizing species follows without any significant interaction, just as the cover ratio of sown species. Lastly, the significance of total biomass analyzing both treatments separately has to be emphasized. Among them, the annual behaviour was similar, but in 1998 there was a great increase of biomass in LD sowing mixtures, which allows the significant interaction (Figure 14).

Results of repeated measurement ANOVA (P-values) are shown in Table 4. The 

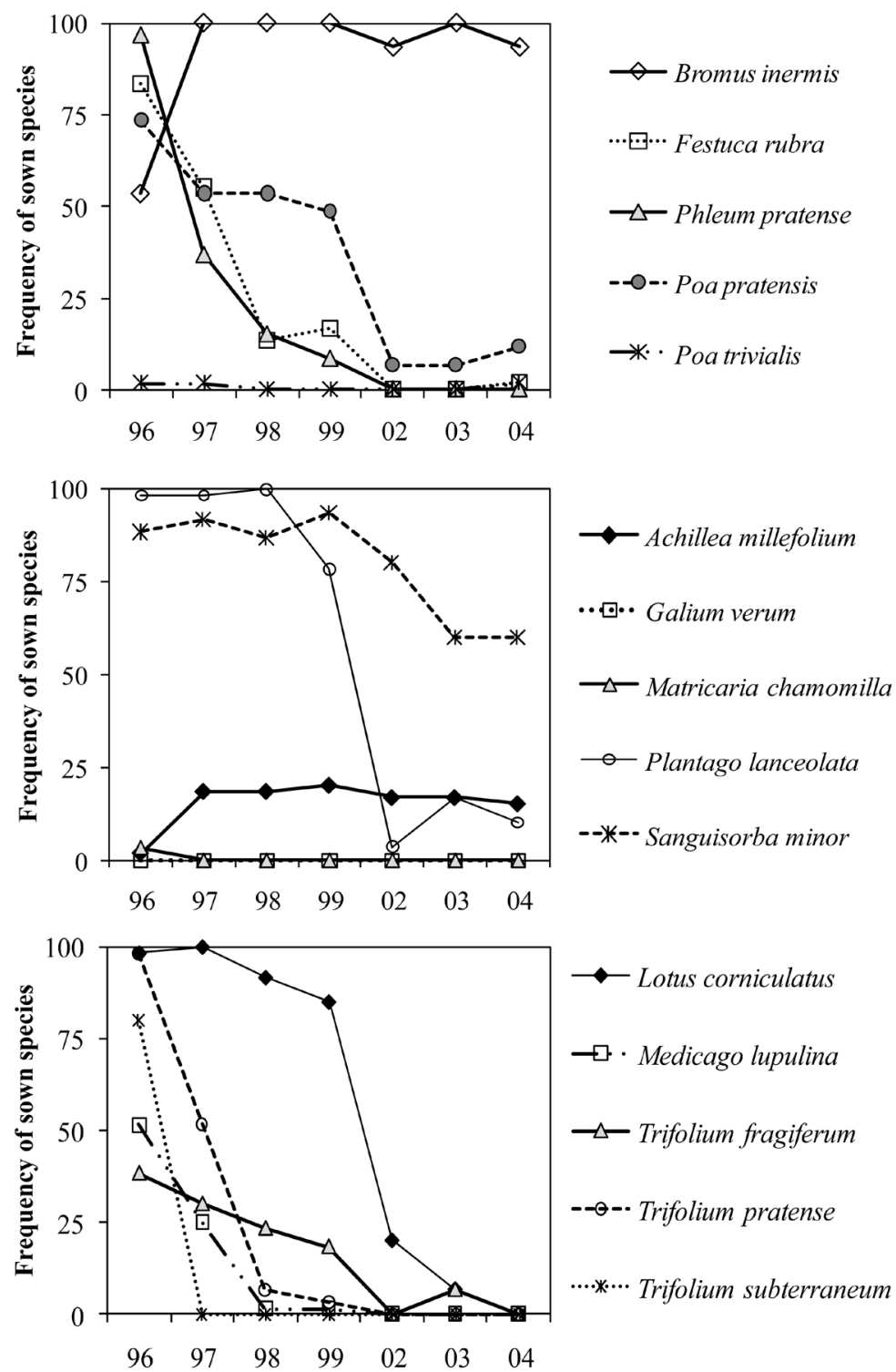

Figure 13. Frequency of the sown species per functional groups in each of the HD plots for the experimental sampling period. The data of the sampling species in subplots $1-\mathrm{m}{ }^{\star} 1-\mathrm{m}$ are shown.

ANOVA model included three main plot factors (treatment, year and treatment-year interaction). The increase of colonizing species cover was significantly lower in LD, which again supports the increase of biomass in 1998, being also lower in HD. Therefore, this increase in the community is more prominent in LD treatments. The effect of sown species was not so important in this increase.

\section{Discussion}

\subsection{Suppression of Colonizer Species}

Suppression of early colonizing plant species was presumed to be one of the primary mechanisms driving secondary succession in old-field plant communities [8] [27]. The 

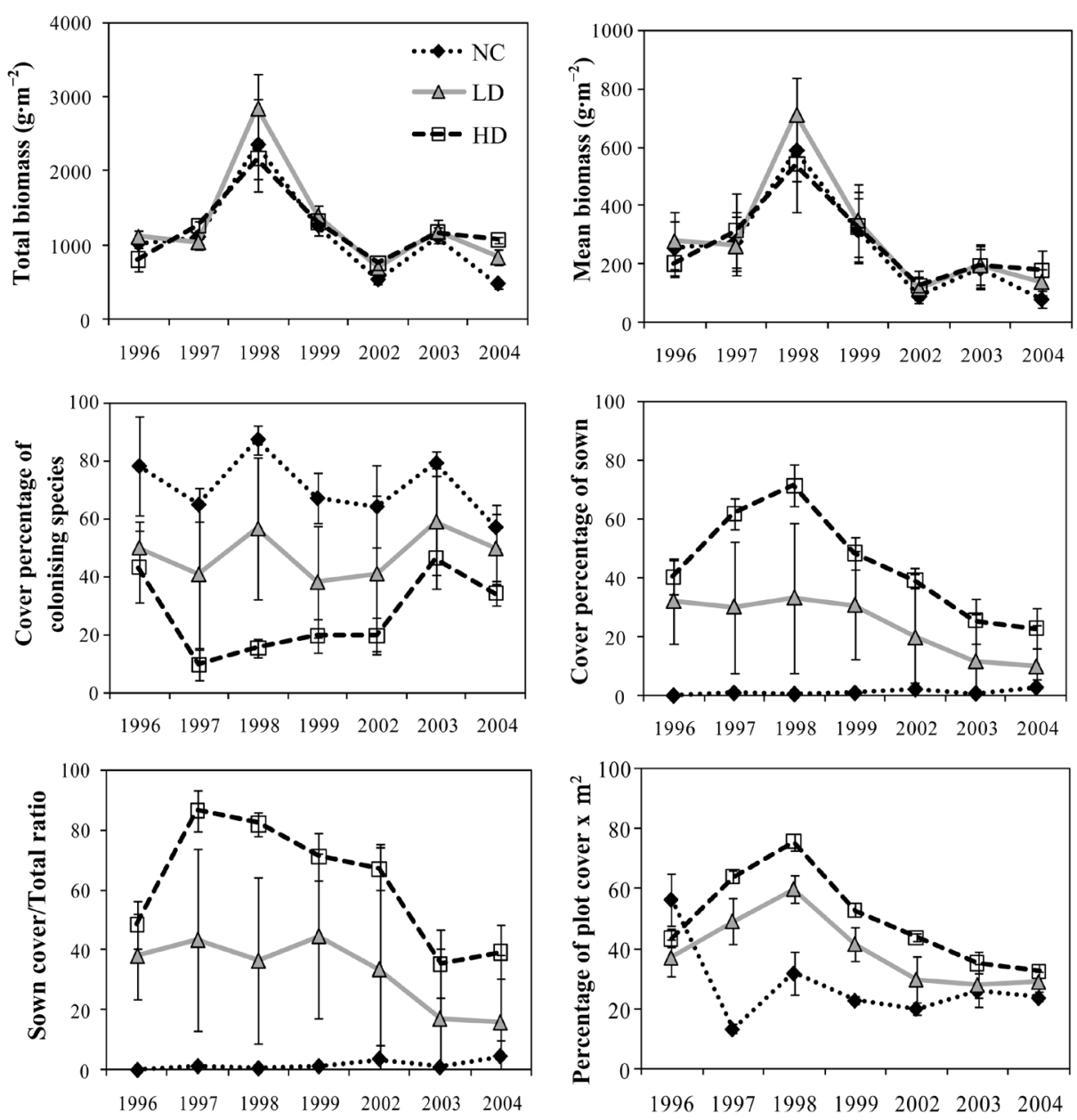

Figure 14. Average values of different plant properties in each different treatment for natural colonisation (NC, no later-succesional plant species sown), and for sowing later-succesional plant species in low-diversity (LD, 4 sown species) and high-diversity (HD, 15 sown species) treatments. Error bars extend between minimum and maximum value of the five blocks.

Table 4. Results of repeated measurement ANOVA (P-values). The ANOVA model included three main plot factors (treatment, year and treatment-year interaction). Significant terms $(\boldsymbol{P}<$ 0.05 ) are shown in bold.

\begin{tabular}{ccccccc}
\hline Variables & $\mathrm{Tr}$ & $\mathrm{Y}$ & $\mathrm{Tr}^{*} \mathrm{Y}$ & HD-LD & $\mathrm{Y}$ & HD-LD *A \\
\hline \multicolumn{7}{c}{ Whole-plots } \\
\hline Sown species & $\mathbf{0 . 0 0 0}$ & $\mathbf{0 . 0 0 0}$ & $\mathbf{0 . 0 0 0}$ & $\mathbf{0 . 0 0 0}$ & $\mathbf{0 . 0 0 0}$ & $\mathbf{0 . 0 0 0}$ \\
Colonising species colonizadoras & 0.129 & $\mathbf{0 . 0 0 0}$ & 0.614 & 0.420 & $\mathbf{0 . 0 0 0}$ & 0.871 \\
All species & 0.576 & $\mathbf{0 . 0 0 0}$ & $\mathbf{0 . 0 4 7}$ & 0.292 & $\mathbf{0 . 0 0 0}$ & 0.173 \\
Total biomass & 0.187 & $\mathbf{0 . 0 0 0}$ & 0.228 & 0.239 & $\mathbf{0 . 0 0 0}$ & $\mathbf{0 . 0 1 8}$ \\
Sown species cover & $\mathbf{0 . 0 0 1}$ & $\mathbf{0 . 0 0 0}$ & $\mathbf{0 . 0 0 0}$ & 0.068 & $\mathbf{0 . 0 0 0}$ & $\mathbf{0 . 0 2 3}$ \\
Colonising species cover & $\mathbf{0 . 0 0 1}$ & $\mathbf{0 . 0 0 0}$ & $\mathbf{0 . 0 0 0}$ & 0.067 & $\mathbf{0 . 0 0 0}$ & $\mathbf{0 . 0 2 0}$ \\
Sown/Total cover & $\mathbf{0 . 0 0 1}$ & $\mathbf{0 . 0 0 0}$ & $\mathbf{0 . 0 0 0}$ & 0.083 & $\mathbf{0 . 0 0 0}$ & 0.194 \\
& \multicolumn{2}{c}{ Sub-plots } & & & & \\
Sown species & $\mathbf{0 . 0 0 0}$ & $\mathbf{0 . 0 0 0}$ & $\mathbf{0 . 0 0 0}$ & $\mathbf{0 . 0 0 0}$ & $\mathbf{0 . 0 0 0}$ & $\mathbf{0 . 0 0 0}$ \\
Colonising species & $\mathbf{0 . 0 1 2}$ & $\mathbf{0 . 0 0 0}$ & $\mathbf{0 . 0 3 0}$ & 0.198 & $\mathbf{0 . 0 0 0}$ & 0.190 \\
All species & 0.280 & $\mathbf{0 . 0 0 0}$ & $\mathbf{0 . 0 0 0}$ & 0.075 & $\mathbf{0 . 0 0 0}$ & $\mathbf{0 . 0 0 1}$ \\
Total biomass & 0.268 & $\mathbf{0 . 0 0 0}$ & 0.344 & 0.197 & $\mathbf{0 . 0 0 0}$ & $\mathbf{0 . 0 1 2}$ \\
\hline
\end{tabular}



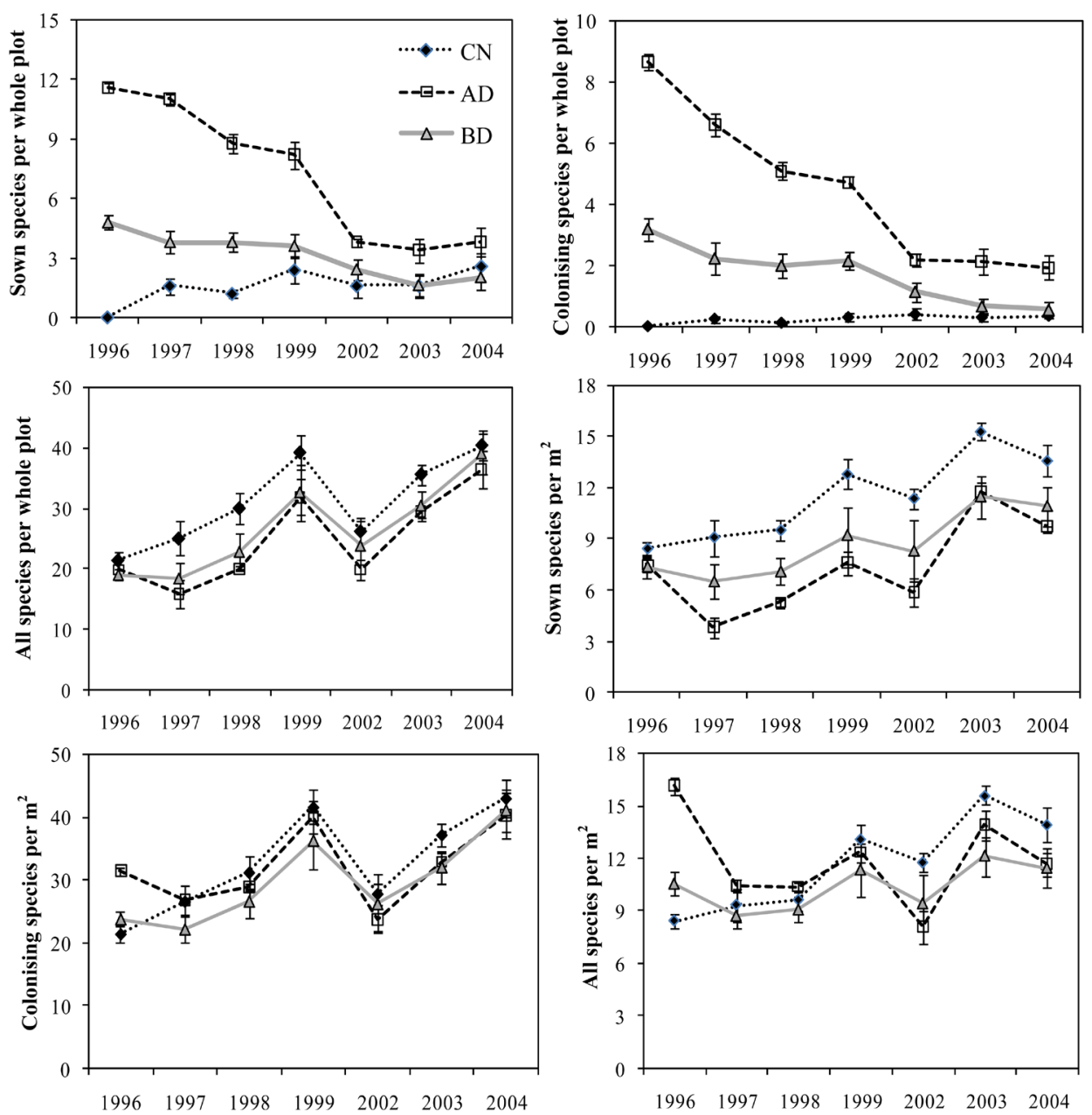

Figure 15. Numbers of total species, colonizer and sown plant species in each different treatment for natural colonisation (NC, no later-succesional plant species sown), and for sowing later-succesional plant species in low-diversity (LD, 4 sown species) and high-diversity (HD, 15 sown species) treatments. Error bars extend between minimum and maximum value of the five blocks.

development of plant communities is often affected by the presence of strong dominants [47]. At locations with invasion potential of the species from a nearby target community, one should be aware that sowing mixtures could suppress desired natural colonization. It seems that highly suppressive mixtures were either the high diversity ones, or the ones composed of strong competitors. However, the presence of a strong competitor in a mixture not only suppresses the colonizers, but also leads to decreased survival of other sown species.

The sown species failed to establish successfully and were unable to eliminate the weeds for competition. Until 1998, the sown species were successful in suppressing the colonizer species, but their competitive effect decreased noteworthy the following year, when the number of colonizer species increased significantly (F $=30.30 ; 6$ d.f.; $\boldsymbol{P}<$ 0.000). From this year until the end of the experiment in 2004, the number of colonizing species diversity in both plots stabilized because they did not differ significantly 
from the peak reached in 1999First, the suppressing effect of the high diversity treatment showed more homogeneity among replicates than that of the low diversity mixtures. This demonstrates that the different low diversity mixtures had variable effects on weed suppression. Starting from the second season, the number of colonizers began to differentiate according to the treatments, being on the lowest average in the $\mathrm{HD}$ and highest in the NC plots. The development of the community is often affected by the presence of strong dominants, and it depends on the local conditions and on the presence of species that are able to attain high dominance under given condition [23].

When there was a significant increase in the number of colonizer species in high diversity seed mixtures (1999 and 2004), it is largely due to the divergence in the number of colonizer species among blocks, but most of all the blocks 1, 3 and 5 contributed mainly to this differentiation (Figure 2). For the other years when the number remained constant in all blocks, there was a similarity in the behavior of all blocks. On the other hand, in low diversity seed mixtures, the number of colonizer species was different for each of the blocks, for each of the years, due to the effect of different sown species mixtures. Nevertheless, the common behavior of treatment was due to combined effect of four blocks. The block 2 where there was mixed B. inermis and Sanguisorba minor, was only taking a low number of colonizer species during all experimental process, even in 1999 and 2004 when there was a significant increase in the number of those colonizer species.

For every year, except 1996, the low values of index $D_{1}(<0.4)$ found showed that in all communities not subjected to sowing effect (NC), there was no dominant species that affects the growth of the other species by competitive exclusion. Similarly, the high level of variability of $\mathrm{HD} / \mathrm{NC}$ ratio among years; demonstrates that in some of them, the sown species were more effective in suppressing the numbers of colonising species (low values), especially in 1997 and 1998. The general found model shows that in most of years, there was no dominant specie in NC, with the exception of the first year of experimentation (1996), where only the perennial colonizer grass Poa sp. species showed a high dominance. In this same year, the annual other-forb, Polygonum aviculare, was also dominant, but only in this year for both sowing of low and high diversity seed mixtures treatments.

The negative relationship $(\mathrm{r}=-0.87)$ found supports that, low values of index $D_{1}$, the number of dominant colonizer species by block increased for most of the years. This fact was very relevant, because the sowing effect may be explained not only by suppressing colonizer species, but also for its effect on the number of dominant species income, that can be considered as a positive effect on the increase of diversity by sowing.

At the beginning of the experiment, only Polygonum aviculare was dominant and was quickly replaced by the sown species, but mostly by B. inermis and Sanguisorba minor. Nevertheless, at the same time that some species disappeared, other species began to dominate in the established community in HD from 1999; the other annual forbs Barkhausia taraxacifolia and Lactuca serriola were the most important in this year. In 2002, the annual grass Vulpia bromoides was emphasized. In 2003, B. taraxacifolia y L. serriola were again dominant, together with a high number of colonizer species that 
remained until the following year (2004), but the other annual-forb species Geranium molle and the other perennial-forb species Carduus tenuiflorus were the most important among the colonizer dominant species.

\subsection{Dominance of Sown Species}

Large differences were recorded among individual sown species. Some of them were abundant in sown plots, but rarely or never spread to other plots. This suggests that dispersal limitation is an important factor for determining the composition of plant community [48] [49]. In general, plant traits are important determinants of species success in restoration [50], and the ability to spread is amongst the most important ones.

The main goal that was obtained through diversity manipulation was to identify the effect of biodiversity on ecosystem processes and its implications in the restoration of abandoned arable lands. In natural conditions, there are many limitations due to other factors correlated with diversity, species composition and other characteristics common to herbaceous plant species, and can minimize the importance of diversity on some ecosystem processes [51] [52]. Experimentally, this problem can be solved, but further effect remains; the species identity [33], which in turn can also be solved if in the experimental design, it was considered that each LD treatment contains sown species mixtures that were a subset of the species sown mixtures in HD treatment, so that each one have the same importance in all examined levels.

The cover of sown species in LD and HD treatments for the experimental sampling period was compared with a PCA analysis, in order to estimate which of them showed a similar performance under conditions of different sowing, and to separate in this way, the diversity effects and the species identity on the removal of weeds. The model allows us to know if the cover of sown species in HD were independent of cover of the same species in the LD blocks.

\subsection{Performance of the Sown Species}

The HD mixtures were more successful when comparing the success of sowing of HD and LD mixtures, measured either by proportion of sown species, by suppression of natural colonizers, or by the total biomass, on average. However, the most successful LD mixture was usually equally successful as the HD mixtures. This suggests that diversity was important primarily for its "insurance effect" [23] [53]. Whilst some of the LD mixtures failed to establish successfully, the HD mixtures were always able to compensate the failure of some species to establish. Often, the presence of the dominant grass was enough for the LD mixture qualify as "the best", even if the other species in the combination exhibited low cover, or even fail to survive. However, weed suppression and later-succession species invasion depended on the performance of species introduced. The strongest effect on weed suppression may result from the growth characteristics of the species used.

Community assembly often leads to a single stable equilibrium, such that the condi- 
tions of the environment and interspecific interactions determine which species will exist there. In such cases, regions of local communities with similar environmental conditions should have similar community composition. The resulting community depends on the assembly history, even when all species have access to the community. Both regional and local factors should determine the patterns by which communities assemble, and the resultant degree of similarity or dissimilarity among localities with similar environments.

Within the group of grasses, which competes properly in natural conditions, its participation in the community matrix during the experimental period was especially noticeable. Festuca rubra, Phleum pratense and Poa pratensis were successfully established in the plots, but they disappeared quickly, without becoming dominants, whereas Poa trivialis remains with very low values for cover during all experimental process. Within the group of other forbs, $S$. minor was important during all experimental time, just as $P$. lanceolata, but without maintaining its character of dominant until the end of the experiment. Among the remaining three species, none was important, and even the seeds of Galium verum were unable to grow. Within the group of sown legumes, Lotus corniculatus was the only species well established, but the persistence varied considerably over time. Medicago lupulina and the three species of Trifolium disappeared quickly.

The treatment $x$ year interaction was highly significant for most of the variables tested, indicating that the growth of vegetation for individual year have high specific properties (20). Besides, the cover of colonizing species varied with respect to treatments and years, but it does not vary with respect to the number of species which naturally colonize the plots, this means that there was no sown effect over species richness.

\subsubsection{Effect of Sowing Species}

The differences found between both diversity treatments may be related with various aspects associated with establishment of the species in both diversity mixtures [33] [54] [55] [56]. Therefore, only four of the fifteen sown species were dominants during most of the years evaluated, whereas half of the remaining species behave as subordinate and others disappear completely, even though all of them are later-successional typical perennial species of a dehesa-like woodland. Furthermore, the success of $B$. inermis badly affected the growth of other forbs group ( $P$. lanceolata, $S$. minor) and the legumes $(L$. corniculatus), which only achieved dominance in absence of the previous species.

There were functional differences among sowing of low and high diversity seed mixtures of later-successional plant species, for example, the grasses were the most important functional group in natural conditions, whereas in the sowing treatments, most of the colonising grasses were inhibited by the dominant sown grass, $B$. inermis. In the same way, Fargione et al. [57] found that each remaining functional group was the most effective inhibiting invasive species of the same functional group. Our results were according to Diamond [58], who assures that there is no importance in the history of invasions, neither that the species invading a community are being highly variables. 
The behaviour of legumes group changed mostly, interacting with the other two functional groups, grasses and other-forbs as found by Turnbull et al. [59]. The sowing of low and high diversity seed mixtures of later-successional plant species showed that the plots containing at least one legume species had a higher availability of nitrogen in the soil [60] [61] [62], which may inhibit the germination of invasive legumes. In our experiment, none colonizer legume was important in the sowing of low and high diversity seed mixtures, whereas $M$. sativa was important in natural colonization for some years.

\subsubsection{Species and Functional Groups Composition}

Our results emphasize the importance of functional species traits and the species identity in addition to species richness per se [63]. Some authors analyze the diversity in terms of species number [19], but other authors consider that the functional diversity that is a factor covarying besides species richness [64]. In our experimental study, only the sowing of high diversity seed mixtures generated a sampling effect [65], increasing the probability of a determined functional group which contains dominant species remaining over time, whereas in the sowing of low diversity seed mixtures, using two grasses for a forb and a legume, is being given greater importance to first group, trying to imitate the top dominance of this group in natural conditions, and to ensure that at least one of them is dominant [19] [66] [67].

The success of sown perennial species was associated with the decrease of species richness, in circumstances where this decrease may attribute to changes in the number of subordinate species (annual colonizers). Presumably, the perennial species were growing as dominant species, with a lot of answers in the vegetative dynamics of leaves and roots (1998), due to available nutrients after the first years of secondary succession of abandoned land. The subordinate plant species may coexist together with the dominant species through a variety of mechanisms. Grime [68] assumes that the associations between certain dominant and subordinate species reflect a complementary habitat exploitation.

Our results support the hypothesis that the response of ecosystem functioning to changing diversity relates more to species traits (maximum height reached, tolerance to stress, high germination rates etc.) than to species number per se [20] [69]. Some authors consider that those traits or functional differences among plant species are the basis of diversity effects on the ecosystem functioning [36] [70]; at the same time, other authors have complemented the definition of functional groups with respect to specific traits [69].

The mechanism for the observed inverse association between invader performance and resident species richness is associated with interspecific competition for space, light, and nutrients with neighbours [70]. Multiple regression analyses showed that the decrease of biomass and cover was significantly associated with the relative abundance of sown species and in the lesser proportion of resident and colonizer species. Thereby, we infer that variation in plant diversity is responsible for variation in these factors which in turn affect invader success according to Naeem et al. [21]. 


\section{Conclusions}

Highly suppressive mixtures were either the ones with high diversity, or the ones composed of strong competitors. However, the presence of a strong competitor in a mixture not only suppresses the colonizers, but also leads to decreased survival of other sown species. The sown species failed to establish successfully and were unable to eliminate the weeds for competition. The more successful species during all experimental period was $B$. inermes, followed by $P$. lanceolada.

The negative relationship $(\mathrm{r}=-0.87)$ found supports that, low values of index $D_{1}$, the number of dominant colonizer species by block increased for the most of years. This fact was very relevant, because the sowing effect may be explained not only by suppressing colonizer species, but also for its effect on the number of dominant species income, which can be considered as a positive effect on the increase of diversity by sowing.

The HD mixtures were more successful when comparing the success of sowing HD and LD mixtures, measured either by proportion of sown species, by suppression of natural colonizers, or by the total biomass, on average. However, the most successful LD mixture was usually equally successful as the HD mixtures. Whilst some of the LD mixtures failed to establish successfully, the HD mixtures were always able to compensate for the failure of some species to establish.

The success of sown perennial species was associated with the decrease of species richness, in circumstances where this decrease may attribute to changes in the number of subordinate species (annual colonizers). Presumably, the perennial species were growing as dominant species, with a lot of answers in the vegetative dynamics of leaves and roots (1998), due to available nutrients after the first years of secondary succession of abandoned land.

\section{Acknowledgements}

The experimental work was supported by the Framework IV Environment and Climate Programme of the European Commission, contract number ENV4-CT95-0002. We are indebted to J. Hernández and J.J. Martin for their help.

\section{References}

[1] Vitousek, P.M., Mooney, H.A., Lubchenco, J. and Melillo, J.M. (1997) Human Domination of Earth's Ecosystems. Science, 277, 494-499. http://dx.doi.org/10.1126/science.277.5325.494

[2] Sala, O.E., Chapin, F.S., Armesto, J.J., et al. (2000) Global Biodiversity Scenarios for the Year 2100. Science, 287, 1770-1774. http://dx.doi.org/10.1126/science.287.5459.1770

[3] Kattge, J., et al. (2011) TRY - A Global Database of Plant Traits. Global Change Biology, 17, 2905-2935. http://dx.doi.org/10.1111/j.1365-2486.2011.02451.x

[4] Garnier, E., Navas, M. and Grigulis, K. (2016) Plant Functional Diversity-Organism Traits, Community Structure, and Ecosystem Properties. Oxford University Press, Oxford.

[5] Symstad, A.J. and Tilman, D. (2001) Diversity Loss, Recruitment Limitation, and Ecosys- 
tem Functioning: Lessons Learned from a Removal Experiment. Oikos, 92, 424-435. http://dx.doi.org/10.1034/j.1600-0706.2001.920304.x

[6] Helgason, T., Daniell, T.J., Husband, R., Fitter, A.H. and Young, J.P.W. (1998) Ploughing up the Wood-Wide Web? Nature, 394, 431. http://dx.doi.org/10.1038/28764

[7] Hansson, M. and Fogelfors, H. (1998) Management of Permanent Set-Aside on Arable Land in Sweden. Journal of Applied Ecology, 35, 758-771.

http://dx.doi.org/10.1046/j.1365-2664.1998.355350.x

[8] van der Putten, W.H., Mortimer, S.R., Hedlund, K., van Dijk, C., Brown, V.K., Lepš, J., Rodriguez-Barrueco, C., Roy, J., Diaz Len, T.A., Gormsen, D., Korthals, G.W., Lavorel, S., Santa Regina, I. and Šmilauer, P. (2000) Plant Species Diversity as a Driver of Early Succession in Abandoned Fields: A Multi-Site Approach. Oecologia, 124, 91-99. http://dx.doi.org/10.1007/s004420050028

[9] Armesto, J.J. and Pickett, S.T.A. (1986) Removal Experiments to Test Mechanisms of Plant Succession in Old Fields. Vegetatio, 66, 85-93.

[10] Prach, K. (2003) Spontaneous Succession in Central-European Man-Made Habitats: What Information Can Be Used in Restoration Practice? Applied Vegetation Science, 6, 125-129. http://dx.doi.org/10.1111/j.1654-109X.2003.tb00572.x

[11] Fukami, T., Bezemer, T.M., Mortimer, S.R. and van der Putten, W.H. (2005) Species Divergence and Trait Convergence in Experimental Plant Community Assembly. Ecology Letters, 8, 1283-1290. http://dx.doi.org/10.1111/j.1461-0248.2005.00829.x

[12] Tilman, D. (1999) The Ecological Consequences of Changes in Biodiversity: A Search for General Principles. Ecology, 80, 1455-1474.

[13] Pavoine, S. and Bonsall, M.B. (2011) Measuring Biodiversity to Explain Community Assembly: A Unified Approach. Biological Reviews, 86, 792-812. http://dx.doi.org/10.1111/j.1469-185X.2010.00171.x

[14] Elton, C.S. (1958) The Ecology of Invasions by Animals and Plants. T. Methuen and Co., London. http://dx.doi.org/10.1007/978-1-4899-7214-9

[15] May, R.M. (1972) Will a Large Complex System Be Stable? Nature, 238, 413-414. http://dx.doi.org/10.1038/238413a0

[16] Tilman, D., Wedin, D. and Knops, J. (1996) Productivity and Sustainability Influenced by Biodiversity in Grassland Ecosystems. Nature, 379, 718-720. http://dx.doi.org/10.1038/379718a0

[17] Roy, J. (2001) How Does Biodiversity Control Primary Productivity? In: Roy, J., Saugier, B. and Mooney, H.A., Eds., Global Terrestrial Productivity: Past, Present and Future, Academic Press, San Diego, 169-186.

[18] Gerhold, P., Price, J.N., Püssa, K., Kalamees, R., Aher, K., Kaasik, A. and Pärtel, M. (2013) Functional and Phylogenetic Community Assembly Linked to Changes in Species Diversity in a Long-Term Resource Manipulation Experiment. Journal of Vegetation Science, 24, 843-852. http://dx.doi.org/10.1111/jvs.12052

[19] Leps, J., Brown, V.K., Diaz-Len, T.A., Gormsen, D., Hedlund, K., Kailova, J., Korthals, G.W., Mortimer, S.R., Rodriguez-Barrueco, C., Roy, J., Regina, I.S., van Dijk, C. and van der Putten, W.H. (2001) Separating the Chance Effect from Other Diversity Effects in the Functioning of Plant Communities. Oikos, 92, 123-134.

http://dx.doi.org/10.1034/j.1600-0706.2001.920115.x

[20] Hedlund, K., Santa Regina, I., van der Putten, W.H., Leps, J., Díaz, T., Korthals, G.W., Lavorel, S., Brown, V.K., Gormsen, D., Mortimer, S.R., Barrueco, C.R., Roy, J., Smilauer, P., Smilauerova, M. and Van Dijk, C. (2003) Plant Species Diversity, Plant Biomass and Res- 
ponses of the soil Community on Abandoned Land across Europe: Idiosyncracy or Above-Belowground Time Lags. Oikos, 103, 45-58. http://dx.doi.org/10.1034/j.1600-0706.2003.12511.x

[21] Naeem, S., Knops, J.M.H., Timan, D., Howe, K.M., Kennedy, T. and Gale, S. (2000) Plant Diversity Increases Resistance to Invasion in the Absence of Covarying Extrinsic Factors. Oikos, 91, 97-108. http://dx.doi.org/10.1034/j.1600-0706.2000.910108.x

[22] Bullock, J.M., Pywell, R.F., Burke, M.J.W. and Walker, K.J. (2001) Restoration of Biodiversity Enhances Agricultural Production. Ecology Letters, 4, 185-189. http://dx.doi.org/10.1046/j.1461-0248.2001.00215.x

[23] Cornwell, W.K., et al. (2014) Functional Distinctiveness of Major Plant Lineages. Journal of Ecology, 102, 345-356. http://dx.doi.org/10.1111/1365-2745.12208

[24] Leps, J., Dolezal, J., Bezemer, T.M., Brown, V.K., Hedlund, K., Igual, M., Jorgensen, H.B., Lawson, C.S., Mortimer, S.R., Peix Geldart, A., Rodriguez Barrueco, C., Santa Regina, I., Smilauer, P. and van der Putten, W.H. (2007) Long-Term Effectiveness of Sowing High and Low Diversity Seed Mixtures to Enhance Plant Community Development on Ex-Arable Fields. Applied Vegetation Science, 10, 97-110. http://dx.doi.org/10.1111/j.1654-109X.2007.tb00508.x

[25] O’Gorman, E.J., Yearsley, J.M., Crowe, T.P., Emmerson, M.C., Jacob, U. and Petchey, K.J. (2010) Loss of Functionally Unique Species May Gradually Undermine Ecosystems. Proceedings of the Royal Society of London B, 278, 1886-1893. http://dx.doi.org/10.1098/rspb.2010.2036

[26] Hector, A., Schmid, B., Beierkuhnlein, C., Caldeira, M.C., Diemer, M., Dimitrakopoulos, P.G., Finn, J.A., Freitas, H., Giller, P.S., Good, J., Harris, R., Hogberg, P., Huss-Danell, K., Joshi, J., Jumpponen, A., Korner, C., Leadley, P.W., Loreau, M., Minns, A., Mulder, C.P.H., O’Donovan, G., Otway, S.J., Pereira, J.S., Prinz, A., Read, D.J., Scherer-Lorenzen, M., Schulze, E.D., Siamantziouras, A.S.D., Spehn, E.M., Terry, A.C., Troumbis, A.Y., Woodward, F.I., Yachi, S. and Lawton, J.H. (1999) Plant Diversity and Productivity Experiments in European Grasslands. Science, 286, 1123-1127. http://dx.doi.org/10.1126/science.286.5442.1123

[27] Hooper, D.U., Chapin III, F.S., Ewel, J.J., Hector, A., Inchausti, P., Lavorel, S., Lawton, J.H., Lodge, D.M., Loreau, M., Naeem, S., Schmid, B., Setala, H., Symstad, A.J., Vandermeer, J. and Wardle, D.A. (2005) Effects of Biodiversity on Ecosystem Functioning: A Consensus of Current Knowledge. Ecological Monographs, 75, 3-35. http://dx.doi.org/10.1890/04-0922

[28] Tilman, D. (1988) Plant Strategies and the Dynamics and Structure of Plant Communities. Princeton University Press, Princeton, New Jersey.

[29] Thompson, K. and Grime, J.P. (1988) Conmpetition Reconsidered-A Replay to Tilman. Functional Ecology, 2, 114-116.

[30] de Bello, F., Lavorel, S., Albert, C.H., Thuiller, W., Grigulis, K., Dolezal, J., Janecek, S. and Lepš, J. (2011) Quantifying the Relevance of Intraspecific Trait Variability for Functional Diversity. Methods in Ecology and Evolution, 2, 163-174.

http://dx.doi.org/10.1111/j.2041-210X.2010.00071.x

[31] de Bello, F., Price, J.N., Muenkemueller, T., Liira, J., Zobel, M., Thuiller, W., Gerhold, P., Goetzenberger, L., Lavergne, S., Lepš, J., Zobel, K. and Pärtel, M. (2012) Functional Species Pool Framework to Test for Biotic Effects on Community Assembly. Ecology, 93, 22632273. http://dx.doi.org/10.1890/11-1394.1

[32] Marks, P.L. and Bormann, F.H. (1972) Revegetation Following Forest Cutting: Mechanisms for Return to Steady-State Nutrient Cycling. Science, 176, 914-915. http://dx.doi.org/10.1126/science.176.4037.914 
[33] Huston, M.A. (1997) Hidden Treatments in Ecological Experiments: Re-Evaluating the Ecosystem Function of Biodiversity. Oecologia, 110, 449-460. http://dx.doi.org/10.1007/s004420050180

[34] Naeem, S., Thompson, L.J., Lawler, S.P., Lawton, J.H. and Woodfin, R.M. (1994) Declining Biodiversity Can Alter the Performance of Ecosystems. Nature, 368, 734-737. http://dx.doi.org/10.1038/368734a0

[35] Naeem, S., Thompson, L.J., Lawler, S.P., Lawton, J.H. and Woodfin, R.M. (1995) Empirical Evidence That Declining Species Diversity May Alter the Performance of Terrestrial Ecosystems. Philosophical Transactions of the Royal Society of London Biological Sciences, 347, 249-262. http://dx.doi.org/10.1098/rstb.1995.0025

[36] Tilman, D. (1996) Population versus Ecosystem Stability. Ecology, 77, 350-363. http://dx.doi.org/10.2307/2265614

[37] Tilman, D. (1997) Distinguishing between the Effects of Species Diversity and Species Composition. Oikos, 80, 185. http://dx.doi.org/10.2307/3546532

[38] Lawton, J.H., Naeem, S., Thompson, L.J., Hector, A. and Crawley, M.J. (1998) Biodiversity and Ecosystem Function: Getting the Ecotron Experiment in Its Correct Context. Functional Ecology, 12, 848-852.

[39] Pavoine, S., Vallet, J., Dufour, A.B., Gachet, S. and Daniel, H. (2009) On the Challenge of Treating Various Types of Variables: Application for Improving the Measurement of Functional Diversity. Oikos, 118, 391-402. http://dx.doi.org/10.1111/j.1600-0706.2008.16668.x

[40] Robinson, G.R. and Quinn, J.F. (1988) Extinction, Turnover and Species Diversity in an Experimentally Fragmented California Annual Grassland. Oecologia, 76, 71-81. http://dx.doi.org/10.1007/BF00379603

[41] FAO (1989) The Revised Legend: FAO/UNESCO: Soil Map of the World. FAO, Rome.

[42] Shannon, C.E. (1948) A Mathematical Theory of Communication. The Bell System Technical Journal, 27, 379-423. http://dx.doi.org/10.1002/j.1538-7305.1948.tb01338.x

[43] Camargo, J.A. (1993) Must Dominance Increase with the Number of Subordinate Species in Competitive Interactions? Journal of Theoretical Biology, 161, 537-542. http://dx.doi.org/10.1006/jtbi.1993.1072

[44] Huedo-Medina, T.B., Sánchez-Meca, J., Marín-Martínez, F. and Botella, J. (2006) Assessing Heterogeneity in Meta-Analysis: Q Statistic or I I Index? Psychological Methods, 11, 193206.

[45] Berger, W.H. and Parker, F.L. (1970) Diversity of Planktonic Foraminifera in Deep-Sea Sediments. Science, 168, 1345-1347. http://dx.doi.org/10.1126/science.168.3937.1345

[46] Lepš, J. and Šmilauer, P. (2003) Multivariate Analysis of Ecological Data Using CANOCO. Cambridge University Press, Cambridge. http://dx.doi.org/10.1017/CBO9780511615146

[47] Clarke, P.J., Latz, P.K. and Albrecht, D.E. (2005) Long-Term Changes in Semi-Arid Vegetation: Invasion of an Exotic Perennial Grass Has Larger Effects than Rainfall Variability. Journal of Vegetation Science, 16, 237-248. http://dx.doi.org/10.1111/j.1654-1103.2005.tb02361.x

[48] Ozinga, W.A., Schaminee, J.H.J., Bekker, R.M., Bonn, S., Poschlod, P., Tackenberg, O., Bakker, J. and van Groenendael, J.M. (2005) Predictability of Plant Species Composition from Environmental Conditions Is Constrained by Dispersal Limitation. Oikos, 108, 555561. http://dx.doi.org/10.1111/j.0030-1299.2005.13632.x

[49] van Bodegom, P.M., Douma, J.C. and Verheijen, L.M. (2014) A Fully Traits-Based Approach to Modeling Global Vegetation Distribution. Proceedings of the National Academy of Sciences of the United States of America, 111, 13733-13738. 
http://dx.doi.org/10.1073/pnas.1304551110

[50] Pywell, R.F., Bullock, J.M., Roy, D.B., Warman, L.I.Z., Walker, K.J. and Rothery, P. (2003) Plant Traits as Predictors of Performance in Ecological Restoration. Journal of Applied Ecology, 40, 65-77. http://dx.doi.org/10.1046/j.1365-2664.2003.00762.x

[51] Schläpfer, F. (1999) Expert Estimates about the Effects of Biodiversity on Ecosystem Processes and Services. Oikos, 84, 346-352. http://dx.doi.org/10.2307/3546733

[52] Pierce, S., Brusa, G., Vagge, I. and Cerabolini, B.E.L. (2013) Allocating CSR Plant Functional Types: The Use of Leaf Economics and Size Traits to Classify Woody and Herbaceous Vascular Plants. Functional Ecology, 27, 1002-1010. http://dx.doi.org/10.1111/1365-2435.12095

[53] Yachi, S. and Loreau, M. (2007) Does Complementary Resource Use Enhance Ecosystem Functioning? A Model of Light Competition in Plant Communities. Ecology Letters, 10, 54-62. http://dx.doi.org/10.1111/j.1461-0248.2006.00994.x

[54] Huston, M.A., Aarssen, L.W., Austin, M.P., Cade, B.S., Fridley, J.D., Garnier, E., Grime, J.P., Hodgson, J., Lauenroth, W.K., Thompson, K., Vandermeer, J.H., Wardle, D.A., et al. (2000) No Consistent Effect of Plant Diversity on Productivity. Science, 289, 1255. http://dx.doi.org/10.1126/science.289.5483.1255a

[55] He, J.S., Bazzaz, F.A. and Schmid, B. (2002) Interactive Effects of Diversity, Nutrients and Elevated $\mathrm{CO}_{2}$ on Experimental Plant Communities. Oikos, 97, 337-348. http://dx.doi.org/10.1034/j.1600-0706.2002.970304.x

[56] Brose, U., Martinez, N.D. and Williams, R.J. (2003) Estimating Species Richness: Sensitivity to Sample Coverage and Insensitivity to Spatial Patterns. Ecology, 84, 2364-2377. http://dx.doi.org/10.1890/02-0558

[57] Fargione, J., Brown, C.S. and Tilman, D. (2003) Community Assembly and Invasion: An Experimental Test of Neutral versus Niche Processes. Proceedings of the National Academy of Sciences of the United States of America, 100, 8916-8920. http://dx.doi.org/10.1073/pnas.1033107100

[58] Diamond, J.M. (1975) Assembly of Species Communities. In: Diamond, J.M. and Cody, M.L., Eds., Ecology and Evolution of Communities, Harvard University Press, Boston, 342344.

[59] Turnbull, L.A., Coomes, D.A., Hector, A. and Rees, M. (2004) Seed Mass and the Competition/Colonization Trade-Off: Competitive Interactions and Spatial Patterns in a Guild of Annual Plants. Journal of Ecology, 92, 97-109. http://dx.doi.org/10.1111/j.1365-2745.2004.00856.x

[60] Spehn, E.M., Scherer-Lorenzen, M., Schmid, B., Hector, A., Caldeira, M.C., Dimitrakopoulos, P.G., Finn, J.A., Jumpponen, A., O’Donnovan, G., Pereira, J.S., Schulze, E.D., Troumbis, A.Y. and Körner, C. (2002) The Role of Legumes as a Component of Biodiversity in a Cross-European Study of Grassland Biomass Nitrogen. Oikos, 98, 205-218. http://dx.doi.org/10.1034/j.1600-0706.2002.980203.x

[61] Scherer-Lorenzen, M., Palmborg, C., Prinz, A. and Schulze, E.D. (2003) The Role of Plant Diversity and Composition for Nitrate Leaching in Grasslands. Ecology, 84, 1539-1552. http://dx.doi.org/10.1890/0012-9658(2003)084[1539:TROPDA]2.0.CO;2

[62] Price, C.A., Wright, I.J., Ackerly, D.D., Niinemets, Ü., Reich, P.B. and Veneklaas, E.J. (2014) Are Leaf Functional Traits "Invariant" with Plant Size and What Is "Invariance" Anyway? Functional Ecology, 28, 1330-1343. http://dx.doi.org/10.1111/1365-2435.12298

[63] Zavaleta, E.S. and Hulvey, K.B. (2007) Realistic Variation in Species Composition Affects Grassland Production, Resource Use and Invasion Resistance. Plant Ecology, 188, 39-51. 
http://dx.doi.org/10.1007/s11258-006-9146-z

[64] Wardle, D.A. (2001) Experimental Demonstration That Plant Diversity Reduces Invasibility-Evidence of a Biological Mechanism or Consequence of a Sampling Effect? Oikos, 95, 161-170. http://dx.doi.org/10.1034/j.1600-0706.2001.950119.x

[65] Schleuter, D., Daufresne, M., Massol, F. and Argillier, C. (2010) A user's Guide to Functional Diversity Indices. Ecological Monographs, 80, 469-484. http://dx.doi.org/10.1890/08-2225.1

[66] Swenson, N.G. (2014) Functional and Phylogentic Ecology in R. Springer, New York. http://dx.doi.org/10.1007/978-1-4614-9542-0

[67] Grime, J.P. (2001) Plant Strategies, Vegetation Processes, and Ecosystem Properties. 2nd Edition, John Wiley \& Sons, Chichester.

[68] Chapin III, F.S., Zavaleta, E.S., Eviner, V.T., Naylor, R.L., Vitousek, P.M., Reynolds, H.L., Hooper, D.U., Lavorel, S., Sala, O.E., Hobbie, S.E., Mack, M.C. and Diaz, S. (2000) Consequences of Changing Biodiversity. Nature, 405, 234-242. http://dx.doi.org/10.1038/35012241

[69] Loreau, M. (1998) Separating Sampling and Other Effects in Biodiversity Experiments. Oikos, 82, 600-602. http://dx.doi.org/10.2307/3546381

[70] Díaz, S. and Cabido, M. (2001) Vive la Difference: Plant Functional Diversity Matters to Ecosystem Processes. Trends in Ecology \& Evolution, 16, 646-655.

http://dx.doi.org/10.1016/S0169-5347(01)02283-2.

Submit or recommend next manuscript to SCIRP and we will provide best service for you:

Accepting pre-submission inquiries through Email, Facebook, LinkedIn, Twitter, etc. A wide selection of journals (inclusive of 9 subjects, more than 200 journals)

Providing 24-hour high-quality service

User-friendly online submission system

Fair and swift peer-review system

Efficient typesetting and proofreading procedure

Display of the result of downloads and visits, as well as the number of cited articles

Maximum dissemination of your research work

Submit your manuscript at: http://papersubmission.scirp.org/

Or contact jep@scirp.org 